\title{
CD38: T Cell Immuno-Metabolic Modulator
}

\author{
Anwesha Kar ${ }^{1}$, Shikhar Mehrotra ${ }^{2, *}$ and Shilpak Chatterjee ${ }^{1, *(1)}$ \\ 1 Cancer Biology and Inflammatory Disorder Division, CSIR-Indian Institute of Chemical Biology, \\ Kolkata 700032, India; anwesha@csiriicb.res.in \\ 2 Department of Surgery, Medical University of South Carolina, Charleston, SC 29425, USA \\ * Correspondence: mehrotr@musc.edu (S.M.); schatterjee@iicb.res.in (S.C.); Tel.: +843-792-9195 (S.M.); \\ Fax: +843-792-2556 (S.M.)
}

Received: 5 June 2020; Accepted: 15 July 2020; Published: 17 July 2020

\begin{abstract}
Activation and subsequent differentiation of $\mathrm{T}$ cells following antigenic stimulation are triggered by highly coordinated signaling events that lead to instilling cells with a discrete metabolic and transcriptional feature. Compelling studies indicate that intracellular nicotinamide adenine dinucleotide $\left(\mathrm{NAD}^{+}\right)$levels have profound influence on diverse signaling and metabolic pathways of $\mathrm{T}$ cells, and hence dictate their functional fate. CD38, a major mammalian $\mathrm{NAD}^{+}$glycohydrolase (NADase), expresses on $\mathrm{T}$ cells following activation and appears to be an essential modulator of intracellular $\mathrm{NAD}^{+}$levels. The enzymatic activity of CD38 in the process of generating the second messenger cADPR utilizes intracellular $\mathrm{NAD}^{+}$, and thus limits its availability to different $\mathrm{NAD}^{+}$consuming enzymes (PARP, ART, and sirtuins) inside the cells. The present review discusses how the CD38-NAD ${ }^{+}$axis affects $\mathrm{T}$ cell activation and differentiation through interfering with their signaling and metabolic processes. We also describe the pivotal role of the CD38-NAD ${ }^{+}$ axis in influencing the chromatin remodeling and rewiring $\mathrm{T}$ cell response. Overall, this review emphasizes the crucial contribution of the $\mathrm{CD}^{2} 8^{-} \mathrm{NAD}^{+}$axis in altering $\mathrm{T}$ cell response in various pathophysiological conditions.
\end{abstract}

Keywords: CD38; $\mathrm{NAD}^{+}, \mathrm{T}$ cell differentiation; metabolism; chromatin remodeling

\section{Introduction}

$\mathrm{T}$ cells have evolved to mount protective response against invading pathogens and cancers, while maintaining tolerance to self-antigens [1,2]. This is particularly governed by the intricate balance between the activation signals (signals required for $\mathrm{T}$ cell activation and clonal proliferation) and inhibitory signals (signals that dampen the $\mathrm{T}$ cell effector response) [3]. While optimum activation signals are required for $\mathrm{T}$ cells to resolve infections and tumor burden, inhibitory signals restrain $\mathrm{T}$ cells from mounting immune response against self-antigens.

Activation of T cells following encountering of "non-self" foreign pathogens or "self" tumor antigens occurs in a highly coordinated fashion [4]. To be fully activated, T cells require three distinctive receptor mediated activation signals, "signal 1" which is delivered through TCR upon recognition of cognate antigen presented by MHC [4,5], "signal 2" through co-stimulatory molecules like CD28, GITR, OX-40, etc. [3], and "signal 3" through cytokine-cytokine receptor interaction [6]. Failure in engaging any of the three signals results in transducing sub-optimal strength signal for $\mathrm{T}$ cell activation, which finally leads to $T$ cell anergy $[7,8]$.

Similar to activation, the magnitude and durability of the $\mathrm{T}$ cell response are also kept in tight check by various cellular mechanisms to avoid the collateral damage of host tissues due to exaggerated inflammation. It is known that the expression of various co-inhibitory receptors, such as PD1, CTLA4, Lag3, Tim3, on T cells serves as a brake to counterbalance the activation signals initiated by the stimulatory receptors $[3,9]$. Therefore, co-inhibitory receptors seem to play a pivotal role in $\mathrm{T}$ cell 
homeostasis by controlling $\mathrm{T}$ cell effector response and thus have major implications in diverse disease pathobiology, including cancer and autoimmunity [10].

In addition to various co-stimulatory and co-inhibitory $\mathrm{T}$ cell receptors, ectonucleotidases that regulate the extracellular concentration of nucleotides, are also considered pivotal in modulating $\mathrm{T}$ cell response [11,12]. It has been shown that ectonucleotidases like CD39 and CD73 can promote an immunosuppressive microenvironment in various diseases like cancer, autoimmunity, and allergy through generation of adenosine by sequential cleavage of extracellular ATP to AMP and AMP to adenosine [11]. By doing this conversion, CD39 and CD73 impinge on purinergic signaling in T cells by limiting the availability of purinergic mediator ATP, and hence mitigate the pro-inflammatory response of $\mathrm{T}$ cells [12]. This demonstrates the emerging role of ectonucletidases as key regulator in determining the generation of inflammatory vs. immunosuppressive $\mathrm{T}$ cell response.

In recent years, CD38, another critical ectonucleotidase has gained prominence as an important regulator of $\mathrm{T}$ cell activation and function $[13,14]$. CD38 is a multifunctional transmembrane ectoenzyme that belongs to nicotinamide adenine dinucleotide $\left(\mathrm{NAD}^{+}\right)$glycohydrolase/adenosine $5^{\prime}$-diphosphate-ribosyl cyclase gene family. The enzymatic activity of CD38 not only catalyzes the cyclization of $\mathrm{NAD}^{+}$to cyclic ADP-ribose (cADPR), but also hydrolyzes cADPR to form ADP-ribose (ADPR) [15]. Interestingly, it has been shown that a small amount of $\mathrm{NAD}^{+}$gets cyclized by CD38 to produce cADPR, while the majority is hydrolyzed to ADPR [16]. This observation led to the proposition that the major enzymatic activity of CD38 is NAD ${ }^{+}$glycohydrolase (NADase), but not ADP-ribosyl cyclase. In addition to $\mathrm{NAD}^{+}, \mathrm{CD} 38$ has also been shown to hydrolyze nicotinamide adenine dinucleotide phosphate (NADP) into nicotinic acid adenine dinucleotide phosphate (NAADP) via a base-exchange reaction [17]. However, the reaction requires an acidic $\mathrm{pH}$ and high (millimolar) concentration of nicotinic acid, the conditions can only be attained in vitro but hardly possible in vivo [17]. In fact, this notion was further supported by the observation that shRNA mediated knockdown of CD38 in Jurkat T cells had no effect in altering the intracellular concentration of NAADP, suggesting the dispensable role of CD38 in generating NAADP [18].

Numerous studies suggest that CADPR generated by the enzymatic action of CD38 acts as a second messenger for intracellular $\mathrm{Ca}^{2+}$ mobilization in several cells $[19,20]$. This indicates a plausible involvement of CD38 in regulating $\mathrm{T}$ cell activation [14,21], given the unequivocal role of $\mathrm{Ca}^{2+}$ signaling in triggering $\mathrm{T}$ cell activation. In fact, it has been reported that the expression of CD38 accompanies $\mathrm{T}$ cell activation and predominantly localizes to the immune synapse in close contact with $\mathrm{T}$ cell receptor (TCR) [22]. Moreover, the NAD ${ }^{+}$glycohydrolase (NADase) activity of CD38 which determines the intracellular level of $\mathrm{NAD}^{+}$[16], a principal metabolite regulating diverse biochemical and cellular processes further evinces the pivotal role of CD38 in regulating $\mathrm{T}$ cell functionality. Here in, we will focus on how CD38 is involved in regulating T cell-mediated immunity.

\section{CD38-NAD ${ }^{+}$Axis in Health and Diseases}

CD38 was discovered as a cell surface marker present on the thymocytes and activated T cell surface and initially termed as T10 [23,24]. The enzymatic activities of CD38 generating ADPR and cADPR were described by Berthelier et al. and De Flora et al. [25,26]. A decade later, this molecule drew attention after Edward Chini and colleagues unearthed the role of CD38 as a major NAD ${ }^{+}$catabolizing enzyme having a number of pathophysiological implications in aging, infection, and tumorigenesis [15].

High expression of CD38 has often been found to be associated with several hematological malignancies [27,28]. For example, the pathogenic role of CD38 have been implicated in multiple myeloma (MM), where tumor cells exhibit high surface expression of CD38 [29,30]. Likewise, CD38 expression is reported in other hematological tumors including B cell-chronic lymphocytic leukemia, acute myeloid leukemia, acute lymphocyte leukemia, and acute promyelocytic leukemia [31]. Owing to high CD38 expression, therapeutic interventions targeting CD38 are being devised for various hematological malignancies. Recently, monoclonal antibody targeting CD38 has been approved by FDA for the treatment of patients with refractory $\operatorname{MM}[27,28,32,33]$. Conversely to hematological tumors, 
malignant cells from solid tumors do not express CD38. However, emerging studies are indicating that immune cells of both lymphoid and myeloid origin present at solid tumor sites exhibit high cell surface expression of CD38, which negatively correlates with the prognosis of the disease [13,34,35].

In contrast to causal attribution of CD38 in hematological malignancies many intriguing pieces of evidence suggest that CD38 is an essential component that serves to combat various infections by triggering innate immune response. A study in mice with Listeria monocytogenes infection has shown that upregulation of CD38 on neutrophils and macrophages is essential for their recruitment to the site of infection and efficient pathogen clearance [36]. In accord with this observation, an earlier study in C57BL/6 mice with Mycobacterium avium infection also implicated the role of CD38 in mounting protective immune response against the pathogen [37]. Mechanistically, CD38 has been shown to facilitate signaling pathways that lead to the production of pro-inflammatory cytokines from DC and macrophages [38-41], which appears to be instrumental in restraining infectious burden. Recent findings also indicate that the expression of CD38 can act as a negative regulator of immune cell function. In multiple myeloma, CD38 is implicated in promoting more aggressive immunosuppressive MDSCs and Treg [42]. A similar observation was also reported in the cases of esophageal and colorectal cancer (CRC) patients, where expression of CD38 potentiates the suppressive function of MDSCs and hence is associated with poor survival of patients [35,43]. These studies thus demonstrate that apart from acting as an adhesion molecule through interaction with CD31 on endothelial cells, CD38 could also tinker with the cellular events leading to distinctive functional outcome by immune cells.

Although, much efforts have been made to elucidate the role of CD38 in B cell malignancies and innate immune cells, its relative contribution in modulating $\mathrm{T}$ cell response is still limiting. Earlier studies reported the expression of $\mathrm{CD} 38$ on human early $\mathrm{T}$ cell precursors and on $\mathrm{CD} 4^{+} \mathrm{CD} 8^{+}$double positive thymocytes [44]. In contrast, mature T cells have low level of CD38 but its expression is enhanced by various lymphocytes activators $[45,46]$. In fact, a number of studies from Fabio Malavasi's group reported that in vitro cross-linking of CD38 with specific monoclonal antibodies on human T cells are capable of inducing its activation, proliferation and cytokine secretion through triggering different signaling events [47-49]. Owing to these facts, CD38 has long been considered as the activation marker for T cells. Most recently, a transient increase in the frequency of both $\mathrm{CD} 4^{+}$and $\mathrm{CD} 8^{+} \mathrm{CD} 38^{+} \mathrm{HLA}-\mathrm{DR}{ }^{+}$ $\mathrm{T}$ cells was observed in the blood sample from patient with COVID-19 during the viral clearance phase (day 7-9) [50]. This population (CD4 ${ }^{+}$and $\mathrm{CD} 8^{+} \mathrm{CD} 38^{+} \mathrm{HLA}-\mathrm{DR}{ }^{+} \mathrm{T}$ cells) has been shown to be positively corelated with the improved outcome of the patient [50]. However, CD38 has also been characterized as a marker of terminally exhausted T cells, which are refractory to the PD1 blockade mediated functional rejuvenation [51,52]. In agreement with this observation, a study from our group also reported that expression of CD38 caused metabolic aberration and compromised anti-tumor response by $\mathrm{T}$ cells [13]. These intriguing evidences suggest a complex role of CD38 in regulating $\mathrm{T}$ cell response through intervening multiple cellular and molecular pathways.

\section{CD38 Mediated Signaling in Activated T Cells}

The importance of CD38 in regulating $\mathrm{T}$ cell function is increasingly appreciated owing to their multifunctional enzymatic activity (both NADase and ADP-ribosyl cyclase), which can deplete intracellular NAD ${ }^{+}$level and generates key signaling mediator, cADPR in T cells concomitantly [14]. However, in lymphocytes, CD38 is present on the plasma membrane in a type II conformation, with its catalytic domain exposed extracellularly [53,54]. This observation aroused the question of how CD38 metabolizes intracellular $\mathrm{NAD}^{+}$and generates cADPR, an intracellular second messenger, while its catalytic domain faces outside. In a study by Zhao et al., this issue was addressed and they found that CD38 could be positioned in the plasma membrane in a type III orientation, with its C-terminal catalytic domain would be facing the cytoplasm [55]. Therefore, the type III conformation of CD38 appears to be crucial for its intracellular signaling activity and hence could be important for mediating the cADPR induced intracellular $\mathrm{Ca}^{2+}$ signaling. 
$\mathrm{Ca}^{2+}$ signaling is known to play a vital role in $\mathrm{T}$ cell activation and differentiation [56]. The engagement of TCR with its cognate antigen in the context of MHC results in an increase in intracellular $\mathrm{Ca}^{2+}$ concentration through store-operated calcium entry (SOCE) and activation of calcium release-activated calcium (CRAC) channels [56]. In T cells, the surge in $\mathrm{Ca}^{2+}$ concentration following TCR stimulation is predominantly triggered by 1,4,5-inositol triphosphate (IP3), which has been shown to mobilize $\mathrm{Ca}^{2+}$ from ER lumen through binding with IP3 receptors (IP3Rs) on ER membrane [57-59]. Although IP3Rs were found to be important for antigen triggered $\mathrm{Ca}^{2+}$ release in $\mathrm{T}$ cells, it could not explain prolonged $(>1 \mathrm{~h}) \mathrm{Ca}^{2+}$ signaling by CRAC as IP3 levels returned to near basal levels within $10 \mathrm{~min}$ following TCR stimulation [60-62]. This led to the possibility of other mechanisms operating in parallel to the IP3-IP3R axis in mobilizing $\mathrm{Ca}^{2+}$ from ER following TCR stimulation. Studies by Geuse et al. had shown that ryanodine receptors (RyRs), another $\mathrm{Ca}^{2+}$ release channel also contributed to $\mathrm{Ca}^{2+}$ release from ER lumen through binding to the second messenger CADPR in a TCR stimulation dependent way. Using high-performance liquid chromatography analysis, they showed that stimulation of the T-cell receptor/CD3 (TCR/CD3) complex resulted in the activation of a soluble ADP-ribosyl cyclase and a sustained increase in intracellular levels of cADPR. Increased cADPR significantly and specifically stimulated type-3 ryanodine receptor, indicating a direct modulatory effect of cADPR on $\mathrm{Ca}^{2+}$ channel opening $[63,64]$ and hence $\mathrm{T}$ cell activation and proliferation. Furthermore, the CD38 mediated cADPR production could indirectly induce increase in intracellular $\mathrm{Ca}^{2+}$ level in $\mathrm{T}$ cells by inhibition of the sarcoendoplasmic reticulum $\mathrm{Ca}^{2+}$ ATPase (SERCA), which facilitates calcium entry into ER from cytosol $[56,65]$. These studies together provide direct evidences that $\mathrm{T}$ cell activation, proliferation, and differentiation could be regulated by the CD38 dependent cADPR-RyR axis owing to its ability to modulate intracellular $\mathrm{Ca}^{2+}$ signaling.

In addition to mobilizing $\mathrm{Ca}^{2+}$ from ER, the role of CD38 induced cADRP-RyR axis in regulating $\mathrm{T}$ cell functionality has also been reported. It was shown that splenocytes from CD38 deficient mice with $M$. avium infection were skewed towards Th2 type and secreted lower IFN- $\gamma$, which correlated with their compromised ability to limit mycobacterial burden [37]. This is in agreement with the earlier observation showing that human $\mathrm{T}$ cells upon CD38 ligation in vitro secreted several pro-inflammatory cytokines, including IFN- $\gamma$, IL-6, GM-CSF, and IL-10 [48]. It can be conceivable that the reported effect of CD38 in regulating cytokines production by $\mathrm{T}$ cells could be mediated through the activation of NFATc1 by cADPR-RyR axis induced $\mathrm{Ca}^{2+}$ signaling [66]. It has been shown that activation-induced $\mathrm{Ca}^{2+}$ influx in T cells results in nuclear localization of NFATc1 that drives the expression of several genes associated with $\mathrm{T}$ cell functionality, including the expression of various cytokines genes [67]. Chromatin immunoprecipitation (ChIP) assay has revealed that NFATc1 has a putative binding site in the regulatory region of IL-2, IL-4, and IFN- $\gamma$ in T cells, and hence can control their expression [67]. Therefore, it seems that $\mathrm{CD} 38$ can act as an upstream regulator of intracellular $\mathrm{Ca}^{2+}$ signaling that could activate NFATc1 and hence determine the functionality of the T cells. Apart from regulating $\mathrm{Ca}^{2+}$ signaling, an association between activation-induced expression of CD38 and triggering of MAPK pathway has also been demonstrated where PTK, CD3-z/ZAP-70/PLC-g1 played a significant role [68]. Considering these findings, CD38-cADPR-Ca ${ }^{2+}$ axis in $\mathrm{T}$ cells must be explored in more detail to further unravel the underlying mechanisms driving $\mathrm{T}$ cell functionality (Figure 1). 


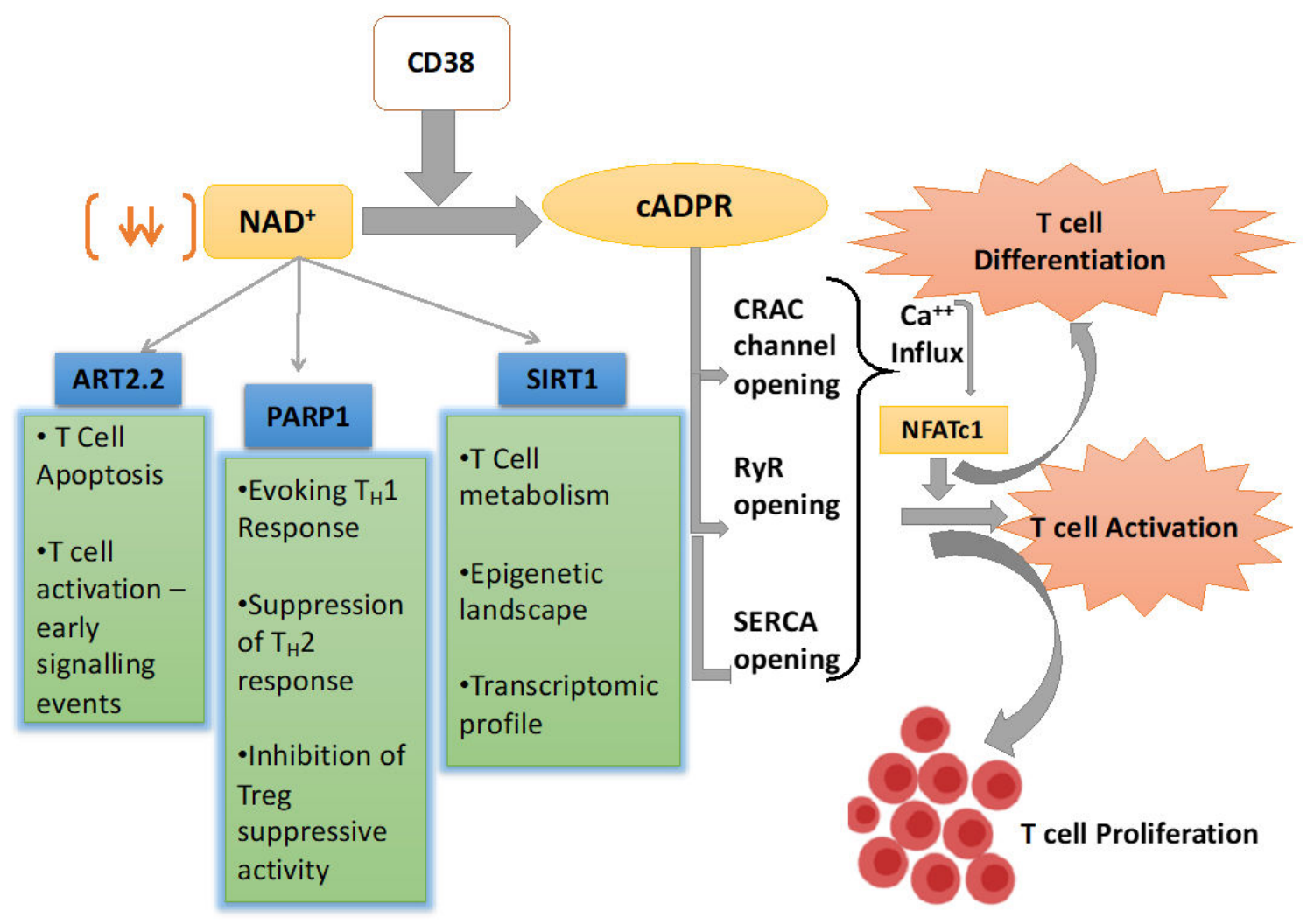

Figure 1. Schematic representation of nicotinamide adenine dinucleotide $\left(\mathrm{NAD}^{+}\right)$utilizing pathways inside the $\mathrm{T}$ cell and their overall effect on $\mathrm{T}$ cell response. CD38 is the major mammalian $\mathrm{NAD}^{+}$ glycohydrolase (NADase) which metabolizes $\mathrm{NAD}^{+}$and generates cyclic ADP-ribose (cADPR), which promotes $\mathrm{T}$ cell activation and proliferations through facilitating $\mathrm{Ca}^{2+}$ signaling. $\mathrm{CD} 38$ expression also depletes $\mathrm{NAD}^{+}$level and hence affect the enzymatic activity of different $\mathrm{NAD}^{+}$consuming enzymes like Sirt1, PARP1, and ART2.2, which play pivotal role in T cell fate determination.

\section{CD38-NAD ${ }^{+}$Axis in Regulating $T$ cell Fate and Function}

CD38 has been identified as a critical modulator of $\mathrm{NAD}^{+}$metabolism owing to its NADase activity $[15,16]$. $\mathrm{NAD}^{+}$is a crucial cellular metabolite being, directly and indirectly, involved in a plethora of signaling pathways. Intracellular $\mathrm{NAD}^{+}$level dependent regulation of various signaling cascades is shown to be mediated through two important enzymes, Poly (ADP-ribose) polymerase (PARP) and sirtuins (Sirt), which utilize NAD ${ }^{+}$as substrate [69-71]. PARP is a family of proteins involved in several cellular processes such as DNA repair, genomic stability, and programmed cell death [72]. Sirt (Sirt1-6) are a class of proteins that possess either mono-ADP-ribosyltransferase, or deacylase activity, including deacetylase, desuccinylase, demalonylase, demyristoylase, and depalmitoylase activity [73]. Several studies reveal that overexpression of CD38 leads to the depletion of intracellular $\mathrm{NAD}^{+}$levels and thus has a profound influence on the activity of the $\mathrm{NAD}^{+}$consuming enzymes (PARP and Sirt), which regulate cellular homeostasis [16].

Alongside the PARPs and Sirt, whose activity is principally governed by the availability of the intracellular $\mathrm{NAD}^{+}$, there exists another class of $\mathrm{NAD}^{+}$consuming enzyme named as ADP-ribosyl transferases or ARTs that act as extracellular $\mathrm{NAD}^{+}$sensors. There are two major isoforms of ARTs-ART2.1 and ART2.2, which are reported to play a critical role in T cell activation and fate determination [74-77]. In addition, directly interfering early events of TCR signaling through producing CADPR, the NADase activity of CD38 could also have a profound influence on various aspects of T cell activation and differentiation. In the next few sections, we will be elaborating, how CD38 dependent modulation of $\mathrm{NAD}^{+}$levels affect different cellular events in $\mathrm{T}$ cells, which in turn dictate the functional and phenotypic outcome of $\mathrm{T}$ cells (Figure 1). 


\subsection{NAD ${ }^{+}$Dependent Mono-ADP-Ribosyl Transferases (ARTs) in T Cells}

Mono-ADP-ribosyl transferases or ARTs are the class of GPI-anchored ecto-enzymes that catalyzes the covalent attachment of ADP-ribose moiety of $\mathrm{NAD}^{+}$to arginine residues on target proteins [72]. Four human (ARTC1, 3, 4, 5) and six mice (ARTC1, 2.1, 2.2, 3, 4, 5) ART proteins have been characterized till now, and their tissue-specific distribution has also been analyzed [78]. The role of ARTs in T cells was ascertained by the observation that treatment with ART inhibitors or ART substrate NAD ${ }^{+}$had a profound effect on mouse T cell proliferation, cytotoxicity, homing, and TCR clustering [74,75,77]. These effects have mainly been attributed to the ART mediated ADP-ribosylation of several T cell surface proteins, including LEF-1 and CD8 [76]. In addition to interfering with T cell activation and cytotoxicity, ART is also implicated in $\mathrm{NAD}^{+}$-induced cell death (NICD) of T cells [79]. It is reported that ART2.2 dependent ADP-ribosylation of P2RX7 represents an alternative pathway of triggering P2RX7 activation on T cells in the presence of extracellular NAD ${ }^{+}[78,79]$. Further, this event leads to $\mathrm{Ca}^{2+} / \mathrm{Na}^{2+}$ influx and efflux of $\mathrm{K}^{+}$ions, shedding of $\mathrm{CD} 62 \mathrm{~L}$, externalization of phosphatidyl serine (PS), cell shrinkage, and ultimately cell death if P2RX7 activation prolonged [79-81]. The notion of extracellular NAD ${ }^{+}$-ART axis mediated $\mathrm{T}$ cell death is further strengthened by the observation that ART2 knockout mice are resistant to NAD-induced apoptosis [82]. However, it has also been shown that $\mathrm{T}$ cells from C57BL/6 mice despite having high ART2, are relatively resistant to the effect of $\mathrm{NAD}^{+}$, suggesting that other factors in addition to ART2.2 are required for NICD of T cells [83]. Contrary to naïve T cells, activated T cells are resistant to NICD—an effect which could be in part due to proteolytic cleavage of ART2.2 from the activated T cell surface $[83,84]$. The reduced enzymatic activity of ART2.2 on activated T cells due to the expression of CD38 could also be critical in this context, as the expression of CD38 on activated T cells has shown to render T cells NICD resistant [85].

Apart from inducing apoptosis in response to extracellular $\mathrm{NAD}^{+}, \mathrm{ARTs}$ also regulate $\mathrm{T}$ cells activation and differentiation. Immuno-precipitation assays using mouse $\mathrm{T}$ cell lines (YAC1 and CTLL2) have confirmed CD25 to be a target for ART2.2 mediated ADP-ribosylation, which occurs at R35 residue of the IL-2 binding site and hence inhibits IL2 signaling via STAT5 [86]. Therefore, it seems that the competition between CD38 and ART2.2 for the occupancy of NAD ${ }^{+}$might dictate the early events of T cell activation as ART2 could attenuate T cell activation by interfering with the IL2 signaling, whereas CD38 dependent CADPR mediated signaling events could promote $\mathrm{T}$ cell activation.

\subsection{NAD Dependent Poly-ADP-Ribose Polymerases in T Cells}

Similar to ARTs, which catalyze extracellular ADP-ribosylation, PARPs are the enzymes responsible for Poly-ADP-ribosylation of nuclear/cytoplasmic proteins [69,72]. Amongst various PARPs, PARP1 accounts for the majority of the poly-(ADPribose) polymer synthesis and functions as a DNA nick sensor binding to single and double strand breaks [87]. Compelling studies are suggesting that PARP-1 can also be activated through different mechanisms other than DNA damage and appear to be important in regulating T cell activation and differentiation [88]. A study by Vlador et al. reported that PARP1 dependent poly-ADP ribosylation negatively regulated the transcriptional activity of NFATc1 and NFATc2 in human T cell line (Jurkat) as this modification expedited nuclear export of NFAT, possibly through priming/facilitating their phosphorylation [89]. In contrast to this report, Olabisi et al. demonstrated that in mouse T cells direct binding and ADP ribosylation of NFAT by PARP1 positively regulated the transcriptional activity of PARP1 through increasing its avidity towards DNA and hence facilitated IL2 production and T cell activation [90]. The study further revealed that PARP1 and NFAT both individually and synergistically increased IL2 production in mouse T cells upon anti-CD3/anti-CD28 stimulation in a dose-dependent manner, an effect which is lost in PARP1 ${ }^{-/-}$ T cells [90]. In addition to regulating IL2 and IL4, PARP1 has been shown to cause sustained expression of various inflammatory cytokines, including TNF $\alpha$, IL1, IL6, etc. [91]. The mechanistic underpinning of PARP1 induced inflammation is the activation of NF-kB [92,93]. It has been shown that PARylation is vital to retain p65 NF-kB in the nucleolus by decreasing its interaction with Crm1 [94]. 
In mouse T cells, PARP1 has been shown to regulate multiple gene expression, including genes encoding for cytokines and chemokines [95]. Interestingly, PARP1 deficiency in T cells tipped the balance towards Th1 differentiation while demeaned Th2 response [95]. PARP1 mediated regulation of the Th 2 response could be explained by the fact that inhibition of PARP1 facilitates the calpain-mediated degradation of STAT6, which is required for IL4 signaling [96]. In regulatory T cells (Treg), strikingly, it has been reported that activation of PARP1 seems to destabilize FoxP3 and reduce the suppressive activity of Treg [97]. In PARP-1 $1^{-/}$Tregs, Foxp3 has been shown to bind at the conserved non-coding DNA sequence 2 (CNS2) at the foxp3 gene, a region important in maintaining Foxp3 gene expression in Tregs [97]. This report followed the earlier study showing that activation of PARP1 negatively affects the differentiation of Tregs [98].

PARP1 has also been shown to play a crucial role in CD8 $\mathrm{T}$ cell homeostasis. It has been reported that oxidative stress-induced apoptosis of CD8 T cells is mediated through PARP1 activation [99]; possibly the mechanism is being exploited by tumor cells to evade the anti-tumor immune response. These studies together point to the fact that PARP1 activity in T cells has a profound influence in regulating $\mathrm{T}$ cell activation, function, and differentiation. Thus, PARP mediated pathways have emerged as a new CD38 regulated downstream pathway that could be therapeutically exploited to modulate $\mathrm{T}$ cell functions in various disease conditions.

\subsection{NAD ${ }^{+}$-Sirt1 Dependent Regulation of T Cell Function}

Sirt are the members of Class III histone deacetylase (HDAC) with the unique feature of using NAD ${ }^{+}$ as a co-factor [73]. Mammals are known to express seven Sirt (Sirt1-Sirt7) with different subcellular distribution: Sirt1, Sirt6, and Sirt7 are predominantly found in the nucleolus, Sirt2 in the cytoplasm, and Sirt3, Sirt4, and Sirt5 in the mitochondria [73]. It is known that Sirt has widespread implications in different pathophysiological conditions like inflammation, autoimmunity, cardiometabolic diseases, and cancers [100].

\subsubsection{Regulation of T Cell Effector Function}

Amongst different Sirt, Sirt1 has emerged as an essential regulator of determining T cell fates and effector function. T cells isolated from Sirt1 knockout (Sirt1KO) mice exhibited hyper-proliferation and augmented IL2 production, features of hyperactivated T cells, which led to the development of experimental autoimmune encephalomyelitis (EAE) in Sirt1KO mice [101,102]. Subsequent studies underscoring mechanistic insights revealed that expression of Sirt1 could attenuate the activity of different transcription factors, which have shown to be indispensable for dictating $\mathrm{T}$ cell functions and phenotypes [103]. It has been reported that Sirt1 could negatively regulate $\mathrm{T}$ cell activation by inhibiting AP-1 transcriptional activity [104], which binds to the IL2 promoter region and stimulates IL2 production in T cells [105]. Sirt1 mediated negative regulation of T cell activation has also been shown to be mediated by the inhibition of Bclaf1 transcriptional activity [106]. It has been reported that Sirt1 could form a complex with Rel-A (member of NFk $\beta$ family) and p300 (a histone acetyl transferase) at the Bclaf1 promoter region and triggered deacetylation of histone 3 lysine 56 residue (H3K56) at Bclaf1 promoter, led to the suppression of the transcriptional activity of Bclaf1 and hence production of IL2 in T cells [106]. The notion of Sirt1 mediated negative regulation of T cell effector response was further strengthened by the observation that Sirt1 KO mouse showed the development of primary SLE like symptoms characterized by deposition of immune complexes within liver and kidneys, some even exhibited diabetes insipidus-like autoimmune disorder after 2 years of age [107].

\subsubsection{Th2 Response}

In addition to regulating $\mathrm{T}$ cell effector function, Sirt1 exerts a profound effect on the differentiation of T cell subsets. Pharmacological inhibition of Sirt1 in ovalbumin induced murine model of asthma has shown to suppress Th2 differentiation, resulting in reduced airway inflammation in mice [108]. Although, the effect was found to be mediated by compromised ability of lung DC to stimulate Th2 
response in presence of Sirt1 inhibitors (sirtinol and cambinol), T cell intrinsic attenuation of Sirt1 in facilitating its differentiation to Th2 cannot be ruled out [108].

\subsubsection{Th17 Response}

The involvement of Sirt1 in regulating Th17 response is, however, intriguing, with apparently controversial reports having been published. A study by Lim et al. reported that Sirt1 potentiated Th17 response by increasing the transcriptional activity of ROR $\gamma \mathrm{t}$, the signature transcription factor for Th17 generation [109]. The study further reported that T cell-specific genetic ablation of Sirt1 in a mouse model of multiple sclerosis significantly ameliorated the disease condition [109]. The observation is supported by our recent study showing that Sirt1 deacetylase activity is required for the differentiation of Th1/17 hybrid T cells capable of producing IFN $\gamma$ and IL-17 simultaneously and mount robust anti-tumor response [13]. In contrast to these reports, study by Limagne et al. by using Sirt1 pharmacological agonists resveratrol and metformin showed that induction of Sirt1 impedes Th17 generation in mice through deacetylation of STAT3, a post-translational modification that repress nuclear translocation and subsequent STAT3 mediated transcriptional activation of ROR $\gamma T$ [110]. In agreement with this observation, Wang et al. showed that in vivo activation of Sirt1 by NAD ${ }^{+}$treatment delayed the pathogenesis of EAE in C57BL/6 mice by impeding the differentiation of both Th1 and Th17 response through downregulation of NF- $\mathrm{KB}$ [111]. Therefore, more explicit insights are required to unravel the contribution of the Sirt1 axis in regulating Th17 response in varied disease scenarios.

\subsubsection{Treg Differentiation}

Protein deacetylase activity of Sirt1 has been shown to inversely correlates with the suppressive activity of Treg, owing to its crucial role in regulating the stability and transcriptional activity of FoxP3, the signature transcription factor of Treg [112,113]. It has been shown that Sirt1 can bind and deacetylate FoxP3 [112,113], which in turn increases the rate of FoxP3 turnover as deacetylation renders FoxP3 to K48 poly-ubiquitinylated and subjected to proteasomal degradation [114,115]. Further studies reveal that Sirt1 mediated deacetylation of three lysine residues (K31, K262, and K267) in murine FoxP3 not only impedes its stability but also hampers the ability of FoxP3 to bind to DNA and exert transcriptional activity [116]. In addition to post-translational control, targeting Sirt1 has also shown to increase transcript levels of FoxP3 mRNA [113]. Sirt1 mediated transcriptional regulation of FoxP3 could be mediated in part by affecting the acetylation of p65 (RelA) [113], which together with c-Rel promoted the formation of a FoxP3-specific enhanceosome, and hence increased the expression of FoxP3 [117]. As a result, a strategy to increase Treg by targeting Sirt1 has been exploited in various preclinical models of autoimmunity and inflammatory disorders and found that Sirt1 could be used as an essential target to improve Treg numbers and their suppressive activity $[100,113,118]$.

\section{CD38-NAD ${ }^{+}$Axis in T Cell Immuno-Metabolism}

Given the role of $\mathrm{CD} 38$ in modulating intracellular NAD ${ }^{+}$levels, its involvement in regulating the metabolic commitment of $\mathrm{T}$ cells is becoming apparent $[13,14]$. Several studies are shedding light on $\mathrm{CD}^{-} 8^{-} \mathrm{NAD}^{+}-\mathrm{Sirt} 1$ axis as an important metabolic checkpoint having enormous contribution in varied aspects of cellular energy metabolisms, including glycolysis, oxidative phosphorylation (OXPHOS), glutaminolysis, which are inherently associated with dictating $T$ cell functional fate $[13,119,120]$.

A recent study from our group illustrated that the ablation of the surface expression of the CD38 in CD4 T cells exhibited intrinsically higher levels of $\mathrm{NAD}^{+}$, which contributed to the rewiring of metabolic commitment and altered mitochondrial dynamics that renders $T$ cells more effective in terms of anti-tumor immunity [13]. The study further reported that although targeting CD38 concomitantly enhanced Sirt1 activity, but the metabolic changes were independent of Sirt1, as Sirt1 deficiency had minimal effect on metabolic changes observed in CD38 ${ }^{-/-} \mathrm{CD} 4 \mathrm{~T}$ cells [13]. This indicated the possibility that other CD38 dependent pathways could play an essential role in this process. One possibility could be the involvement of other Sirt like Sirt3, as it is reported that CD38 promotes the age-related 
decline of $\mathrm{NAD}^{+}$which causes mitochondrial dysfunction and reduced OXPHOS in Sirt3 dependent manner [121]. The metabolic dysfunctionality observed in the CD38 expressing tumor-infiltrating CD4 T cells [13] could also be mediated by the loss of anti-oxidant potential of T cells. Studies published by our group and others have shown that expression of CD38 inversely regulates the anti-oxidant potential of cells, and loss of CD38 in CD4 T cells significantly increased the expression of various anti-oxidant genes including $\operatorname{Tr} x 1, \operatorname{Tr} x 2$, Sod1, Sod2, and Nrf2 [13,122]. Recently, it has been shown that elevated ROS generation in T cells as a result of diminished anti-oxidant (glutathione) level, led to compromised activation of mTOR and reduced expression of NFAT and Myc, an important transcription factor drives glutaminolysis in T cells [123]. Therefore, further investigation in this direction is needed to delineate the Sirt1 independent role of CD38 in regulating the metabolic features of T cells.

$\mathrm{NAD}^{+}$-Sirt1 axis, which is regulated by the expression of CD38 plays a vital role in determining the metabolic commitment of T cells. Importantly, Sirt1 has shown to promote oxidative phosphorylation and mitochondrial metabolism [124-127], which has appeared to be crucial in the differentiation of memory T cell $[128,129]$. Sirt1 mediated regulation of mitochondrial metabolism is mainly attributed to proteins belonging to peroxisome proliferators $\gamma$ co-activator 1 (PGC-1) family, PGC1 $\alpha$ and PGC1 $\beta[127,130]$. The activity of PGC1 $\alpha$ and PGC1 $\beta$ are known to be promoted via Sirt1 mediated deacetylation. The activation of these proteins facilitates mitochondrial biogenesis and subsequently OXPHOS [130]. Thus, it might be hypothesized that hyperactivity of CD38 alleviates Sirt1 activity and hence perturb mitochondrial biogenesis and OXPHOS, which impinge on memory $\mathrm{T}$ cell differentiation. It should also be noted that Sirt1 could promote the differentiation of long-lived T cells with heightened anti-tumor potential through inhibiting the activity of PPAR $\gamma[131,132]$, which suppresses the induction of lipolysis in T cells [132], a prerequisite for memory T cell differentiation [132,133]. Therefore, it seems that the expression of CD38 on T cells by limiting intracellular NAD ${ }^{+}$levels and Sirt1 activity exerts metabolic perturbations, which ultimately affects $\mathrm{T}$ cell differentiation and functionality. Further investigation is thus needed to delineate the intricate mechanisms which would be useful in devising drugable target to improve the metabolic fitness and hence the functionality of $\mathrm{T}$ cells (Figure 2).

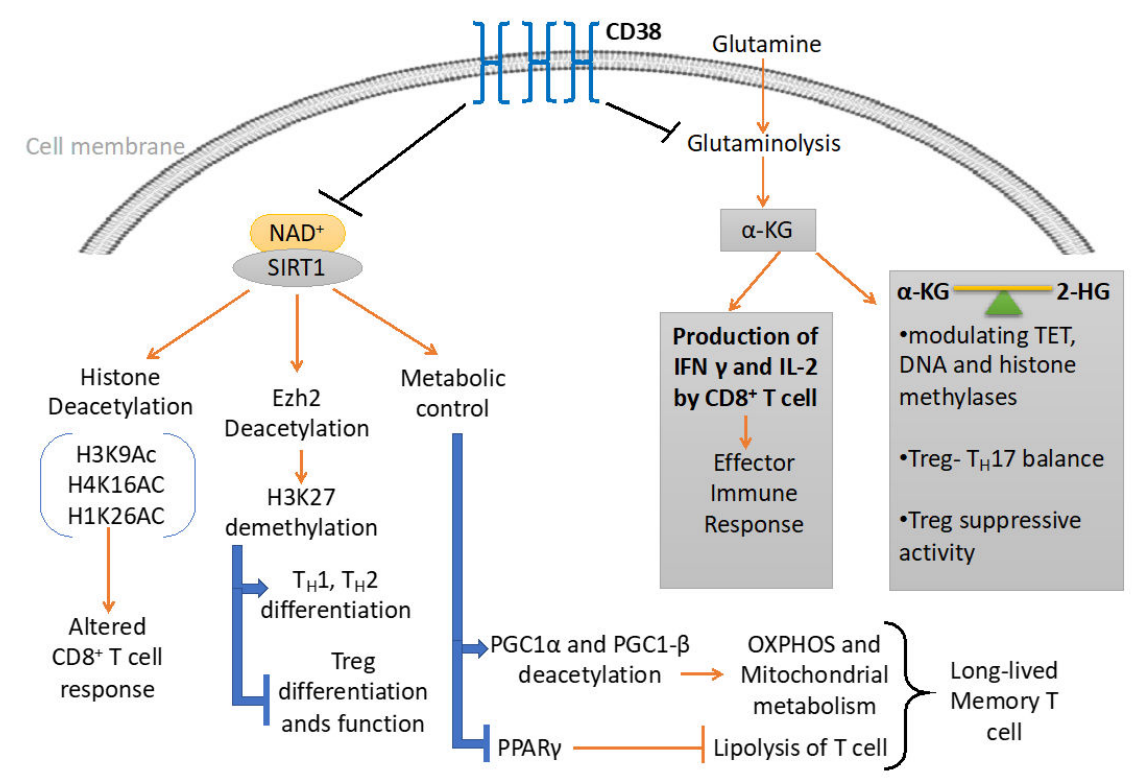

Figure 2. CD38 mediated regulation of metabolic pathways and chromatin modifications in T cells. CD38 affects the differentiation and effector response of $\mathrm{T}$ cells through modulating the metabolic pathways and epigenetic landscape of T cells. On one hand, CD38 curtails the availability of $\mathrm{NAD}^{+}$to Sirt1 and hence attenuates its enzymatic activity which regulates different metabolic and epigenetic pathways in T cells. On the other hand, CD38 inversely regulates glutaminolysis pathways, which not only regulate effector cytokine production in T cells but also produce $\alpha$-ketoglutarate $(\alpha-K G)$ and 2-hydroxyglutarate (2-HG), important epigenetic modifiers. 


\section{CD38-NAD ${ }^{+}$Axis and T Cell Epigenetic Modifications}

CD38, by virtue of its NADase activity, has shown to perturb cellular homeostasis of different NAD ${ }^{+}$ consuming enzymes reported to act as epigenetic modifiers and hence can alter the functional fate of $\mathrm{T}$ cells [134]. Emerging evidence suggests that $\mathrm{CD} 38-\mathrm{NAD}^{+}$axis has a profound influence in regulating the intracellular levels of various metabolites including $\alpha$-ketoglutarate $(\alpha-K G)$, 2-hydroxyglutarate (2-HG), and signaling mediator like ROS, which are reported to play a pivotal role in orchestrating the epigenetic landscape of T cells $[13,135,136]$. Thus, a detailed discussion of these pathways is of utmost importance in the aspect of $\mathrm{T}$ cell differentiation, development, and function.

\subsection{Metabolites Mediated Epigenetic Regulation}

As discussed in the previous section, elevated expression of CD38 on T cells inversely regulates glutaminolysis, a predominant pathway of yielding $\alpha-\mathrm{KG}$, which act as a co-factor of histone and DNA demethylases [13,135]. Recently, it has been reported that $\alpha-K G$ mediated H3K27 demethylation can be linked to the increased effector cytokines (IFN- $\gamma$ and IL-2) production by mouse CD8 ${ }^{+} \mathrm{T}$ cell [137]. The study arouses the possible association of CD38 dependent metabolic rewiring as a critical cellular event regulating the epigenetic modification of $\mathrm{T}$ cells and hence their functional state. This is supported by the recent studies showing that expression of CD38 facilitates T cell exhaustion at the tumor site, which is refractory to restore their functionality by immune checkpoint blockade therapy [52]. This phenomenon is in part due to the extensive epigenetic remodeling of CD38 expressing stable exhausted $\mathrm{T}$ cells $\left(\mathrm{CD} 38^{+} \mathrm{PD} 1^{+} \mathrm{CD} 101^{+} \mathrm{T}\right.$ cells) [52]. Although the detailed mechanisms underpinning CD38 dependent epigenetic modification of $\mathrm{T}$ cells has not been fully explored, altered metabolic commitment of CD38 expressing T cells could play an essential role in this process.

Several studies have reported that a balance between intracellular level of $\alpha-\mathrm{KG}$ and 2-HG, a metabolite produced by isocitrate dehydrogenase 1 and 2 (IDH1/2), are capable of altering histone methylation and chromatin accessibility in various cell types [135,138]. $\alpha$-KG and 2-HG are mutually antagonistic in nature and are found to modulate epigenetic modification of $\mathrm{T}$ cells via affecting the activity of ten-eleven Translocases (TET), DNA, and histone methylases [135]. The intricate balance between $\alpha-\mathrm{KG}$ and 2-HG in instilling epigenetic modification has recently been implicated in fate determination of Th17 and Treg [138]. This is in accordance with the early observation showing that glutaminolysis derived $\alpha-K G$ negatively regulates Treg differentiation [139]. The mechanism could be of further importance in explaining the elevated expression of CD38, particularly on Treg with heightened suppressive activity [42]. It is possible that CD38 mediated negative regulation of glutaminolysis, and hence the production of $\alpha-\mathrm{KG}$ and subsequently 2-HG, maintains demethylation state of FoxP3 promotor that results in increased Treg stability.

\subsection{Sirt1 Dependent Epigenetic Regulation}

$\mathrm{NAD}^{+}$-Sirt1 axis, which is inversely regulated by CD38 expression, has been reported to be an important epigenetic modifier owing to its deacetylation activity [140]. The Sirt1 induced epigenetic regulation can be achieved in three distinct mechanisms, viz., (a) regulation of chromatin structure by histone deacetylation, (b) regulating the activity of transcription factor by deacetylation, and (c) regulation of other epigenetic enzymes by deacetylation [140].

Sirt1 can deacetylate lysine residues of different histone marks, including H3K9Ac, H4K16Ac, and H1K26Ac, as silencing Sirt1 using RNAi approach in human cells led to a global increase in H3K9Ac and H4K16Ac [141]. In human CD8 memory T cells, increased histone acetylation at H3K9 (H3K9Ac), is associated with the activate transcription of EOMES, PRF1, and GZMB loci [142]. However, whether Sirt1 has any role in regulating the acetylation of H3K9 at EOMES, PRF1, and GZMB loci of memory $\mathrm{CD} 8 \mathrm{~T}$ cells has not been fully explored and thus warrants further investigations. 
The role of Sirt1 on imparting distinctive epigenetic signature on T cells could also be mediated through regulating the activity of epigenetic enzymes. It has recently been demonstrated that CD38 ablation mediated elevation of Sirt1 in CD8 T cells from SLE patients is capable of deacetylating enhancer of zeste homolog 2 (Ezh2), an enzyme catalyzing methylation of H3K27 which ultimately causes transcriptional repression [143]. The study further reported that Sirt1 mediated deacetylation of Ezh2 rendered it inactive, resulting in increased transcription of T-bet, EOMES, and Runx3 in CD8 T cells due to reduced Ezh2 mediated H3K27me3 in these gene loci [143]. The study, thus, pointed out the role of CD38-NAD ${ }^{+}$-Sirt1 axis mediated regulation of Ezh2 in determining the cytotoxic potential of CD8 T cells. Ezh2 mediated H3K27 tri-methylation is also reported to regulate Th1, Th2 and Treg differentiation. Ezh2 and increased H3K27 tri-methylation inhibits Th1 and Th2 differentiation as it facilitates the silencing of genes encoding lineage-specific cytokines (like Ifng and il13 for Th1 and Th2, respectively) and transcription factors (T-bet and GATA3 for Th1 and Th2, respectively) [144].

Conversely, expression of Ezh2 promotes Treg cell stability and function, as genetic ablation of Ezh2, specifically in FoxP3 expressing T cells, has shown to suppress Treg cell signature gene FoxP3 [145]. From a recent clinical study, it was found that $\mathrm{T}$ cells from Rheumatoid arthritis (RA) patients exhibited lower Ezh2, which regulated T cell differentiation through promoting epigenetic modification [146]. From in vitro studies, it was concluded that attenuation of Ezh2 led to the downregulation of RUNX1, and promoted SMAD7 which synergistically dampened the TGF $\beta$ signaling events, essential for generation of Tregs [146]. Therefore, it seems reasonable to argue that in addition to directly influencing FoxP3 activity and stability, Sirt1 could indirectly affect the fate of Treg via regulating the enzymatic activity of Ezh2 [112,113] (Figure 2).

\section{Conclusions}

From the above discussion, the multifaceted roles of CD38 in T cell differentiation, development, and different aspects of $\mathrm{T}$ cell health is quite evident. In addition to controlling the different aspects of $\mathrm{T}$ cell activation by interplaying with the TCR downstream signaling pathways, the competition of CD38 with several post-translational and epigenetic modifiers for occupancy of $\mathrm{NAD}^{+}$has been shown to be one of the key dictating factors driving discrete $\mathrm{T}$ cell fates. Even this intricate balance appears to be decisive in regulating the suppressive potential of Treg. It can be speculated from the existing studies that Sirt1 mediated deacetylation of FoxP3, a post-translational event that diminishes the suppressive potential of Treg could be instrumental in regulating the differential suppressive activity between CD38 $8^{\text {hi }}$ and CD38 $8^{\text {lo }}$ Treg. In addition to Sirt1 axis, CD38 mediated metabolic rewiring could also play a crucial role in this context through orchestrating the cellular balance of $\alpha-\mathrm{KG}$ and 2-HG; key glutaminolysis derived metabolites have shown to regulate epigenetic modification. Therefore, it seems that although CD38 expression during activation of T cells might be necessary for mediating early activation events, its stabilization could have a differential effect in defining the functional outcome of different $\mathrm{T}$ cell subsets.

It is also evident from recent studies that CD38 has a crucial role in driving stable exhaustion of T cells, which is refractory to the PD-1 mediated functional rejuvenation. Although the precise mechanism(s) yet to decipher, it seems that epigenetic modification could play a pivotal role in inducing the stable exhausted phenotype of CD38hi $\mathrm{T}$ cells. The notion can be supported by the fact that decreased deacetylase activity of Sirt1 in CD38 ${ }^{\text {hi }} \mathrm{T}$ cells attenuates the enzymatic activity of histone methyltransferase Ezh2 which has a profound effect in determining the functionality and survival of T cells. Depleting CD38 levels in these cells by administration of an antibody against CD38 along with immune checkpoint blockade (anti-PD1) could potentially rejuvenate these cells from being exhausted. These could result in a better manifestation of the anti-tumor property of the tumor-infiltrating $\mathrm{T}$ cells in the advanced stage of a tumor, and in the resolution of any chronic infections, which also induce stable exhaustion phenotype of T cells. However, it should be noted in this context that CD38 antibodies which are available for clinical evaluation including Daratumumab, Isatuximab, MOR202, and TAK-079, cause depletion of target cells through multiple mechanisms 
including antibody dependent cellular cytotoxicity (ADCC), complement dependent cytotoxicity (CDC), antibody dependent cellular phagocytosis (ADCP), etc. [27,147]. Therefore, clinical use of these antibodies to restore the functionality of $\mathrm{CD} 38^{+}$exhausted $\mathrm{T}$ cells in solid tumors or other chorionic infections might cause an adverse effect due to depletion of T cells. Considering this fact, prudent selection of CD38 antibodies specifically targeting the NADase/glycohydrolase activity without triggering target cell cytotoxicity would be extremely important to garner $\mathrm{T}$ cell mediated tumor killing and exploiting this strategy for improved clinical outcomes in solid tumors. The future of CD38 research thus far has much vital information to offer, unraveling some novel downstream mechanisms, and this could emerge as one of the principal pharmacological tools in the hands of the scientific and medical fraternity to modulate functionality $\mathrm{T}$ cells in varied disease scenario.

Author Contributions: Conceptualization, S.C. and S.M.; writing-review and editing, A.K., S.C. and S.M.; supervision, S.C. and S.M. All authors have read and agreed to the published version of the manuscript.

Funding: This work was supported by DBT/Wellcome Trust Intermediate Fellowship IA/I/19/1/504277, Systems Medicine Cluster (SyMEC) project, DBT, India, and SERB extramural fund CRG/2019/001334/BHS awarded to SC; and NIH RO1 CA236379 and RO1 CA250458 to SM.

Conflicts of Interest: The authors declare no potential conflict of interest.

\section{Abbreviations}

$\begin{array}{ll}\text { NAD } & \text { Nicotinamide Adenine Dinucleotide } \\ \text { NADP } & \text { Nicotinamide Adenine Dinucleotide Phosphate } \\ \text { NAADP } & \text { Nicotinic Acid Adenine Dinucleotide Phosphate } \\ \text { ADPR } & \text { Adenosine Di-phosphate Ribose } \\ \text { cADPR } & \text { cyclic Adenosine Di-phosphate Ribose } \\ \text { TCR } & \text { T Cell Receptor } \\ \text { PD1 } & \text { Programmed Death 1 } \\ \text { CTLA4 } & \text { Cytotoxic T-Lymphocyte-Associated protein } 4 \\ \text { Lag3 } & \text { Lymphocyte Activation Gene-3 } \\ \text { Tim3 } & \text { T-cell Immunoglobulin domain and Mucin domain } 3 \\ \text { ATP } & \text { Adenosine Tri-Phosphate } \\ \text { ADP } & \text { Adenosine Di-Phosphate } \\ \text { AMP } & \text { Adenosine Mono-Phosphate } \\ \text { MM } & \text { Multiple Myeloma } \\ \text { DC } & \text { Dendritic Cell } \\ \text { MDSC } & \text { Myeloid Derived Suppressor Cells } \\ \text { Treg } & \text { Regulatory T cells } \\ \text { CRC } & \text { Colo-Rectal Cancer } \\ \text { SOCE } & \text { Store-Operated Calcium Entry } \\ \text { CRAC } & \text { Calcium Release-Activated Channel } \\ \text { IP3 } & \text { Inositol Tri-Phosphate } \\ \text { IP3R } & \text { Inositol Tri-Phosphate Receptor } \\ \text { ER } & \text { Endoplasmic Reticulum } \\ \text { RyR } & \text { Ryanodine Receptor } \\ \text { SERCA } & \text { Sarcoendoplasmic Reticulum Ca }{ }^{2+} \text { ATPase } \\ \text { M. avium } & \text { Mycobacterium avium } \\ \text { IL } & \text { Interleukin } \\ \text { IFN- } \gamma & \text { Interferon } \gamma \\ \text { GM-CSF } & \text { Granulocyte Macrophage Colony Stimulating Factor } \\ \text { NFAT } & \text { Nuclear factor of activated T-cells } \\ \text { NFATc1 } & \text { Nuclear factor of activated T-cells cytoplasmic } 1 \\ \text { NFATc2 } & \text { Nuclear factor of activated T-cells cytoplasmic } 2 \\ & \end{array}$




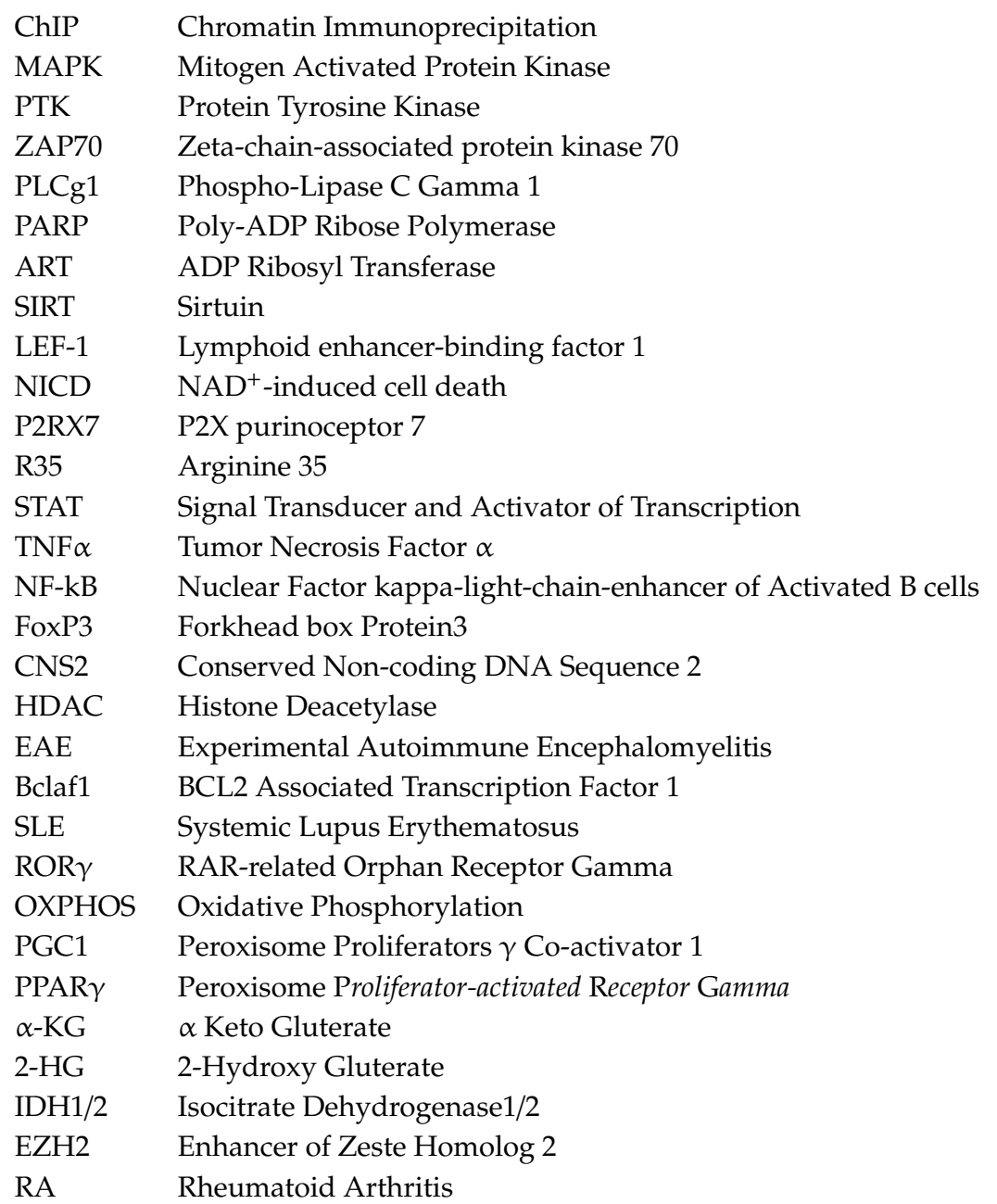

\section{References}

1. Schumacher, T.N.; Gerlach, C.; van Heijst, J.W. Mapping the life histories of T cells. Nat. Rev. Immunol. 2010, 10, 621-631. [CrossRef] [PubMed]

2. Xing, Y.; Hogquist, K.A. T-cell tolerance: Central and peripheral. Cold Spring Harb. Perspect. Biol. $2012,4$. [CrossRef] [PubMed]

3. Chen, L.; Flies, D.B. Molecular mechanisms of T cell co-stimulation and co-inhibition. Nat. Rev. Immunol. 2013, 13, 227-242. [CrossRef] [PubMed]

4. Smith-Garvin, J.E.; Koretzky, G.A.; Jordan, M.S. T cell activation. Annu. Rev. Immunol. 2009, 27, 591-619. [CrossRef]

5. Fulop, T.; Le Page, A.; Garneau, H.; Azimi, N.; Baehl, S.; Dupuis, G.; Pawelec, G.; Larbi, A. Aging, immunosenescence and membrane rafts: The lipid connection. Longev. Healthspan 2012, 1, 6. [CrossRef]

6. Curtsinger, J.M.; Mescher, M.F. Inflammatory cytokines as a third signal for T cell activation. Curr. Opin. Immunol. 2010, 22, 333-340. [CrossRef]

7. Schwartz, R.H. T cell anergy. Annu. Rev. Immunol. 2003, 21, 305-334. [CrossRef]

8. Powell, J.D. The induction and maintenance of T cell anergy. Clin. Immunol. 2006, 120, 239-246. [CrossRef]

9. Attanasio, J.; Wherry, E.J. Costimulatory and Coinhibitory Receptor Pathways in Infectious Disease. Immunity 2016, 44, 1052-1068. [CrossRef]

10. Zhang, Q.; Vignali, D.A. Co-stimulatory and Co-inhibitory Pathways in Autoimmunity. Immunity 2016, 44, 1034-1051. [CrossRef]

11. Bono, M.R.; Fernandez, D.; Flores-Santibanez, F.; Rosemblatt, M.; Sauma, D. CD73 and CD39 ectonucleotidases in T cell differentiation: Beyond immunosuppression. FEBS Lett. 2015, 589, 3454-3460. [CrossRef] [PubMed] 
12. Deaglio, S.; Robson, S.C. Ectonucleotidases as regulators of purinergic signaling in thrombosis, inflammation, and immunity. Adv. Pharm. 2011, 61, 301-332. [CrossRef]

13. Chatterjee, S.; Daenthanasanmak, A.; Chakraborty, P.; Wyatt, M.W.; Dhar, P.; Selvam, S.P.; Fu, J.; Zhang, J.; Nguyen, H.; Kang, I.; et al. CD38-NAD(+)Axis Regulates Immunotherapeutic Anti-Tumor T Cell Response. Cell Metab. 2018, 27, 85-100.e8. [CrossRef] [PubMed]

14. Hogan, K.A.; Chini, C.C.S.; Chini, E.N. The Multi-faceted Ecto-enzyme CD38: Roles in Immunomodulation, Cancer, Aging, and Metabolic Diseases. Front. Immunol. 2019, 10, 1187. [CrossRef] [PubMed]

15. Aksoy, P.; White, T.A.; Thompson, M.; Chini, E.N. Regulation of intracellular levels of NAD: A novel role for CD38. Biochem. Biophys. Res. Commun. 2006, 345, 1386-1392. [CrossRef]

16. Chini, E.N. CD38 as a regulator of cellular NAD: A novel potential pharmacological target for metabolic conditions. Curr. Pharm. Des. 2009, 15, 57-63. [CrossRef]

17. Aarhus, R.; Graeff, R.M.; Dickey, D.M.; Walseth, T.F.; Lee, H.C. ADP-ribosyl cyclase and CD38 catalyze the synthesis of a calcium-mobilizing metabolite from NADP. J. Biol. Chem. 1995, 270, 30327-30333. [CrossRef]

18. Schmid, F.; Bruhn, S.; Weber, K.; Mittrucker, H.W.; Guse, A.H. CD38: A NAADP degrading enzyme. FEBS Lett. 2011, 585, 3544-3548. [CrossRef]

19. Lin, W.K.; Bolton, E.L.; Cortopassi, W.A.; Wang, Y.; O’Brien, F.; Maciejewska, M.; Jacobson, M.P.; Garnham, C.; Ruas, M.; Parrington, J.; et al. Synthesis of the $\mathrm{Ca}(2+)$-mobilizing messengers NAADP and cADPR by intracellular CD38 enzyme in the mouse heart: Role in beta-adrenoceptor signaling. J. Biol. Chem. 2017, 292, 13243-13257. [CrossRef]

20. Kwong, A.K.; Chen, Z.; Zhang, H.; Leung, F.P.; Lam, C.M.; Ting, K.Y.; Zhang, L.; Hao, Q.; Zhang, L.H.; Lee, H.C. Catalysis-based inhibitors of the calcium signaling function of CD38. Biochemistry 2012, 51, 555-564. [CrossRef]

21. States, D.J.; Walseth, T.F.; Lee, H.C. Similarities in amino acid sequences of Aplysia ADP-ribosyl cyclase and human lymphocyte antigen CD38. Trends Biochem. Sci. 1992, 17, 495. [CrossRef]

22. Munoz, P.; Mittelbrunn, M.; de la Fuente, H.; Perez-Martinez, M.; Garcia-Perez, A.; Ariza-Veguillas, A.; Malavasi, F.; Zubiaur, M.; Sanchez-Madrid, F.; Sancho, J. Antigen-induced clustering of surface CD38 and recruitment of intracellular CD38 to the immunologic synapse. Blood 2008, 111, 3653-3664. [CrossRef] [PubMed]

23. Reinherz, E.L.; Kung, P.C.; Goldstein, G.; Levey, R.H.; Schlossman, S.F. Discrete stages of human intrathymic differentiation: Analysis of normal thymocytes and leukemic lymphoblasts of T-cell lineage. Proc. Natl. Acad. Sci. USA 1980, 77, 1588-1592. [CrossRef] [PubMed]

24. Terhorst, C.; van Agthoven, A.; LeClair, K.; Snow, P.; Reinherz, E.; Schlossman, S. Biochemical studies of the human thymocyte cell-surface antigens T6, T9 and T10. Cell 1981, 23, 771-780. [CrossRef]

25. Berthelier, V.; Tixier, J.M.; Muller-Steffner, H.; Schuber, F.; Deterre, P. Human CD38 is an authentic NAD(P)+ glycohydrolase. Biochem. J. 1998, 330, 1383-1390. [CrossRef]

26. De Flora, A.; Guida, L.; Franco, L.; Zocchi, E. The CD38/cyclic ADP-ribose system: A topological paradox. Int. J. Biochem. Cell Biol. 1997, 29, 1149-1166. [CrossRef]

27. Van de Donk, N.; Richardson, P.G.; Malavasi, F. CD38 antibodies in multiple myeloma: Back to the future. Blood 2018, 131, 13-29. [CrossRef]

28. Morandi, F.; Horenstein, A.L.; Costa, F.; Giuliani, N.; Pistoia, V.; Malavasi, F. CD38: A Target for Immunotherapeutic Approaches in Multiple Myeloma. Front. Immunol. 2018, 9, 2722. [CrossRef]

29. Stevenson, F.K.; Bell, A.J.; Cusack, R.; Hamblin, T.J.; Slade, C.J.; Spellerberg, M.B.; Stevenson, G.T. Preliminary studies for an immunotherapeutic approach to the treatment of human myeloma using chimeric anti-CD38 antibody. Blood 1991, 77, 1071-1079. [CrossRef]

30. Costa, F.; Vescovini, R.; Bolzoni, M.; Marchica, V.; Storti, P.; Toscani, D.; Accardi, F.; Notarfranchi, L.; Dalla Palma, B.; Manferdini, C.; et al. Lenalidomide increases human dendritic cell maturation in multiple myeloma patients targeting monocyte differentiation and modulating mesenchymal stromal cell inhibitory properties. Oncotarget 2017, 8, 53053-53067. [CrossRef]

31. Deaglio, S.; Mehta, K.; Malavasi, F. Human CD38: A (r)evolutionary story of enzymes and receptors. Leuk. Res. 2001, 25, 1-12. [CrossRef]

32. Van de Donk, N.W.; Moreau, P.; Plesner, T.; Palumbo, A.; Gay, F.; Laubach, J.P.; Malavasi, F.; Avet-Loiseau, H.; Mateos, M.V.; Sonneveld, P.; et al. Clinical efficacy and management of monoclonal antibodies targeting CD38 and SLAMF7 in multiple myeloma. Blood 2016, 127, 681-695. [CrossRef] [PubMed] 
33. de Weers, M.; Tai, Y.T.; van der Veer, M.S.; Bakker, J.M.; Vink, T.; Jacobs, D.C.; Oomen, L.A.; Peipp, M.; Valerius, T.; Slootstra, J.W.; et al. Daratumumab, a novel therapeutic human CD38 monoclonal antibody, induces killing of multiple myeloma and other hematological tumors. J. Immunol. 2011, 186, 1840-1848. [CrossRef] [PubMed]

34. Konen, J.M.; Fradette, J.J.; Gibbons, D.L. The Good, the Bad and the Unknown of CD38 in the Metabolic Microenvironment and Immune Cell Functionality of Solid Tumors. Cells 2019, 9. [CrossRef] [PubMed]

35. Karakasheva, T.A.; Waldron, T.J.; Eruslanov, E.; Kim, S.B.; Lee, J.S.; O’Brien, S.; Hicks, P.D.; Basu, D.; Singhal, S.; Malavasi, F.; et al. CD38-Expressing Myeloid-Derived Suppressor Cells Promote Tumor Growth in a Murine Model of Esophageal Cancer. Cancer. Res. 2015, 75, 4074-4085. [CrossRef] [PubMed]

36. Lischke, T.; Heesch, K.; Schumacher, V.; Schneider, M.; Haag, F.; Koch-Nolte, F.; Mittrucker, H.W. CD38 controls the innate immune response against Listeria monocytogenes. Infect. Immun. 2013, 81, 4091-4099. [CrossRef]

37. Viegas, M.S.; do Carmo, A.; Silva, T.; Seco, F.; Serra, V.; Lacerda, M.; Martins, T.C. CD38 plays a role in effective containment of mycobacteria within granulomata and polarization of Th1 immune responses against Mycobacterium avium. Microbes. Infect. 2007, 9, 847-854. [CrossRef]

38. Matalonga, J.; Glaria, E.; Bresque, M.; Escande, C.; Carbo, J.M.; Kiefer, K.; Vicente, R.; Leon, T.E.; Beceiro, S.; Pascual-Garcia, M.; et al. The Nuclear Receptor LXR Limits Bacterial Infection of Host Macrophages through a Mechanism that Impacts Cellular NAD Metabolism. Cell Rep. 2017, 18, 1241-1255. [CrossRef]

39. Amici, S.A.; Young, N.A.; Narvaez-Miranda, J.; Jablonski, K.A.; Arcos, J.; Rosas, L.; Papenfuss, T.L.; Torrelles, J.B.; Jarjour, W.N.; Guerau-de-Arellano, M. CD38 Is Robustly Induced in Human Macrophages and Monocytes in Inflammatory Conditions. Front. Immunol. 2018, 9, 1593. [CrossRef]

40. Fedele, G.; Frasca, L.; Palazzo, R.; Ferrero, E.; Malavasi, F.; Ausiello, C.M. CD38 is expressed on human mature monocyte-derived dendritic cells and is functionally involved in CD83 expression and IL-12 induction. Eur. J. Immunol. 2004, 34, 1342-1350. [CrossRef]

41. Lande, R.; Urbani, F.; Di Carlo, B.; Sconocchia, G.; Deaglio, S.; Funaro, A.; Malavasi, F.; Ausiello, C.M. CD38 ligation plays a direct role in the induction of IL-1beta, IL-6, and IL-10 secretion in resting human monocytes. Cell Immunol. 2002, 220, 30-38. [CrossRef]

42. Feng, X.; Zhang, L.; Acharya, C.; An, G.; Wen, K.; Qiu, L.; Munshi, N.C.; Tai, Y.T.; Anderson, K.C. Targeting CD38 Suppresses Induction and Function of T Regulatory Cells to Mitigate Immunosuppression in Multiple Myeloma. Clin. Cancer Res. 2017, 23, 4290-4300. [CrossRef] [PubMed]

43. Karakasheva, T.A.; Dominguez, G.A.; Hashimoto, A.; Lin, E.W.; Chiu, C.; Sasser, K.; Lee, J.W.; Beatty, G.L.; Gabrilovich, D.I.; Rustgi, A.K. CD38+ M-MDSC expansion characterizes a subset of advanced colorectal cancer patients. JCI Insight 2018, 3. [CrossRef] [PubMed]

44. Tenca, C.; Merlo, A.; Zarcone, D.; Saverino, D.; Bruno, S.; De Santanna, A.; Ramarli, D.; Fabbi, M.; Pesce, C.; Deaglio, S.; et al. Death of T cell precursors in the human thymus: A role for CD38. Int. Immunol. 2003, 15, 1105-1116. [CrossRef]

45. Malavasi, F.; Funaro, A.; Alessio, M.; DeMonte, L.B.; Ausiello, C.M.; Dianzani, U.; Lanza, F.; Magrini, E.; Momo, M.; Roggero, S. CD38: A multi-lineage cell activation molecule with a split personality. Int. J. Clin. Lab. Res. 1992, 22, 73-80. [CrossRef]

46. Deterre, P.; Berthelier, V.; Bauvois, B.; Dalloul, A.; Schuber, F.; Lund, F. CD38 in T- and B-cell functions. Chem. Immunol. 2000, 75, 146-168. [CrossRef]

47. Funaro, A.; Spagnoli, G.C.; Ausiello, C.M.; Alessio, M.; Roggero, S.; Delia, D.; Zaccolo, M.; Malavasi, F. Involvement of the multilineage CD38 molecule in a unique pathway of cell activation and proliferation. J. Immunol. 1990, 145, 2390-2396.

48. Ausiello, C.M.; la Sala, A.; Ramoni, C.; Urbani, F.; Funaro, A.; Malavasi, F. Secretion of IFN-gamma, IL-6, granulocyte-macrophage colony-stimulating factor and IL-10 cytokines after activation of human purified T lymphocytes upon CD38 ligation. Cell Immunol. 1996, 173, 192-197. [CrossRef]

49. Ausiello, C.M.; Urbani, F.; la Sala, A.; Funaro, A.; Malavasi, F. CD38 ligation induces discrete cytokine mRNA expression in human cultured lymphocytes. Eur. J. Immunol. 1995, 25, 1477-1480. [CrossRef]

50. Thevarajan, I.; Nguyen, T.H.O.; Koutsakos, M.; Druce, J.; Caly, L.; van de Sandt, C.E.; Jia, X.; Nicholson, S.; Catton, M.; Cowie, B.; et al. Breadth of concomitant immune responses prior to patient recovery: A case report of non-severe COVID-19. Nat. Med. 2020, 26, 453-455. [CrossRef] 
51. Chen, L.; Diao, L.; Yang, Y.; Yi, X.; Rodriguez, B.L.; Li, Y.; Villalobos, P.A.; Cascone, T.; Liu, X.; Tan, L.; et al. CD38-Mediated Immunosuppression as a Mechanism of Tumor Cell Escape from PD-1/PD-L1 Blockade. Cancer. Discov. 2018, 8, 1156-1175. [CrossRef] [PubMed]

52. Philip, M.; Fairchild, L.; Sun, L.; Horste, E.L.; Camara, S.; Shakiba, M.; Scott, A.C.; Viale, A.; Lauer, P.; Merghoub, T.; et al. Chromatin states define tumour-specific T cell dysfunction and reprogramming. Nature 2017, 545, 452-456. [CrossRef] [PubMed]

53. Malavasi, F.; Funaro, A.; Roggero, S.; Horenstein, A.; Calosso, L.; Mehta, K. Human CD38: A glycoprotein in search of a function. Immunol. Today 1994, 15, 95-97. [CrossRef]

54. Jackson, D.G.; Bell, J.I. Isolation of a cDNA encoding the human CD38 (T10) molecule, a cell surface glycoprotein with an unusual discontinuous pattern of expression during lymphocyte differentiation. J. Immunol. 1990, 144, 2811-2815.

55. Zhao, Y.J.; Lam, C.M.; Lee, H.C. The membrane-bound enzyme CD38 exists in two opposing orientations. Sci. Signal. 2012, 5, ra67. [CrossRef]

56. Feske, S. Calcium signalling in lymphocyte activation and disease. Nat. Rev. Immunol. 2007, 7, 690-702. [CrossRef]

57. Iino, M.; Endo, M. Calcium-dependent immediate feedback control of inositol 1,4,5-triphosphate-induced Ca2+ release. Nature 1992, 360, 76-78. [CrossRef]

58. Bezprozvanny, I.; Watras, J.; Ehrlich, B.E. Bell-shaped calcium-response curves of Ins(1,4,5)P3- and calcium-gated channels from endoplasmic reticulum of cerebellum. Nature 1991, 351, 751-754. [CrossRef]

59. Harnick, D.J.; Jayaraman, T.; Ma, Y.; Mulieri, P.; Go, L.O.; Marks, A.R. The human type 1 inositol 1,4,5-trisphosphate receptor from $\mathrm{T}$ lymphocytes. Structure, localization, and tyrosine phosphorylation. J. Biol. Chem. 1995, 270, 2833-2840. [CrossRef]

60. Guse, A.H.; Roth, E.; Emmrich, F. Intracellular Ca2+ pools in Jurkat T-lymphocytes. Biochem. J. 1993, 291, 447-451. [CrossRef]

61. Donnadieu, E.; Cefai, D.; Tan, Y.P.; Paresys, G.; Bismuth, G.; Trautmann, A. Imaging early steps of human T cell activation by antigen-presenting cells. J. Immunol. 1992, 148, 2643-2653. [PubMed]

62. Guse, A.H. Ca2+ signaling in T-lymphocytes. Crit. Rev. Immunol. 1998, 18, 419-448. [CrossRef] [PubMed]

63. Guse, A.H.; da Silva, C.P.; Berg, I.; Skapenko, A.L.; Weber, K.; Heyer, P.; Hohenegger, M.; Ashamu, G.A.; Schulze-Koops, H.; Potter, B.V.; et al. Regulation of calcium signalling in T lymphocytes by the second messenger cyclic ADP-ribose. Nature 1999, 398, 70-73. [CrossRef] [PubMed]

64. Langhorst, M.F.; Schwarzmann, N.; Guse, A.H. Ca2+ release via ryanodine receptors and Ca2+ entry: Major mechanisms in NAADP-mediated Ca2+ signaling in T-lymphocytes. Cell Signal. 2004, 16, 1283-1289. [CrossRef] [PubMed]

65. Park, S.A.; Hong, B.Z.; Ha, K.C.; Kim, U.H.; Han, M.K.; Kwak, Y.G. Protein tyrosine phosphatase 1B is a mediator of cyclic ADP ribose-induced $\mathrm{Ca}(2+)$ signaling in ventricular myocytes. Exp. Mol. Med. 2017, 49, e341. [CrossRef]

66. Gwack, Y.; Feske, S.; Srikanth, S.; Hogan, P.G.; Rao, A. Signalling to transcription: Store-operated Ca2+ entry and NFAT activation in lymphocytes. Cell Calcium 2007, 42, 145-156. [CrossRef]

67. Klein-Hessling, S.; Muhammad, K.; Klein, M.; Pusch, T.; Rudolf, R.; Floter, J.; Qureischi, M.; Beilhack, A.; Vaeth, M.; Kummerow, C.; et al. NFATc1 controls the cytotoxicity of CD8(+) T cells. Nat. Commun. 2017, 8, 511. [CrossRef]

68. Zubiaur, M.; Guirado, M.; Terhorst, C.; Malavasi, F.; Sancho, J. The CD3-gamma delta epsilon transducing module mediates CD38-induced protein-tyrosine kinase and mitogen-activated protein kinase activation in Jurkat T cells. J. Biol. Chem. 1999, 274, 20633-20642. [CrossRef]

69. Hurtado-Bages, S.; Knobloch, G.; Ladurner, A.G.; Buschbeck, M. The taming of PARP1 and its impact on $\mathrm{NAD}(+)$ metabolism. Mol. Metab. 2020, 100950. [CrossRef]

70. Yaku, K.; Okabe, K.; Nakagawa, T. NAD metabolism: Implications in aging and longevity. Age. Res. Rev. 2018, 47, 1-17. [CrossRef]

71. Kupis, W.; Palyga, J.; Tomal, E.; Niewiadomska, E. The role of sirtuins in cellular homeostasis. J. Physiol. Biochem. 2016, 72, 371-380. [CrossRef]

72. Morales, J.; Li, L.; Fattah, F.J.; Dong, Y.; Bey, E.A.; Patel, M.; Gao, J.; Boothman, D.A. Review of poly (ADP-ribose) polymerase (PARP) mechanisms of action and rationale for targeting in cancer and other diseases. Crit. Rev. Eukaryot. Gene. Expr. 2014, 24, 15-28. [CrossRef] 
73. Bheda, P.; Jing, H.; Wolberger, C.; Lin, H. The Substrate Specificity of Sirtuins. Annu. Rev. Biochem. 2016, 85, 405-429. [CrossRef]

74. Okamoto, S.; Azhipa, O.; Yu, Y.; Russo, E.; Dennert, G. Expression of ADP-ribosyltransferase on normal T lymphocytes and effects of nicotinamide adenine dinucleotide on their function. J. Immunol. 1998, 160, 4190-4198. [PubMed]

75. Liu, Z.X.; Yu, Y.; Dennert, G. A cell surface ADP-ribosyltransferase modulates T cell receptor association and signaling. J. Biol. Chem. 1999, 274, 17399-17401. [CrossRef] [PubMed]

76. Nemoto, E.; Yu, Y.; Dennert, G. Cell surface ADP-ribosyltransferase regulates lymphocyte function-associated molecule-1 (LFA-1) function in T cells. J. Immunol. 1996, 157, 3341-3349.

77. Wang, J.; Nemoto, E.; Kots, A.Y.; Kaslow, H.R.; Dennert, G. Regulation of cytotoxic T cells by ecto-nicotinamide adenine dinucleotide (NAD) correlates with cell surface GPI-anchored/arginine ADP-ribosyltransferase. J. Immunol. 1994, 153, 4048-4058.

78. Rissiek, B.; Haag, F.; Boyer, O.; Koch-Nolte, F.; Adriouch, S. ADP-ribosylation of P2X7: A matter of life and death for regulatory T cells and natural killer T cells. Curr. Top. Microbiol. Immunol. 2015, 384, $107-126$. [CrossRef]

79. Seman, M.; Adriouch, S.; Scheuplein, F.; Krebs, C.; Freese, D.; Glowacki, G.; Deterre, P.; Haag, F.; Koch-Nolte, F. NAD-induced T cell death: ADP-ribosylation of cell surface proteins by ART2 activates the cytolytic P2X7 purinoceptor. Immunity 2003, 19, 571-582. [CrossRef]

80. Gu, B.; Bendall, L.J.; Wiley, J.S. Adenosine triphosphate-induced shedding of CD23 and L-selectin (CD62L) from lymphocytes is mediated by the same receptor but different metalloproteases. Blood 1998, 92, 946-951. [CrossRef]

81. Taylor, S.R.; Gonzalez-Begne, M.; Dewhurst, S.; Chimini, G.; Higgins, C.F.; Melvin, J.E.; Elliott, J.I. Sequential shrinkage and swelling underlie P2X7-stimulated lymphocyte phosphatidylserine exposure and death. J. Immunol. 2008, 180, 300-308. [CrossRef] [PubMed]

82. Ohlrogge, W.; Haag, F.; Lohler, J.; Seman, M.; Littman, D.R.; Killeen, N.; Koch-Nolte, F. Generation and characterization of ecto-ADP-ribosyltransferase ART2.1/ART2.2-deficient mice. Mol. Cell Biol. 2002, 22, 7535-7542. [CrossRef] [PubMed]

83. Adriouch, S.; Ohlrogge, W.; Haag, F.; Koch-Nolte, F.; Seman, M. Rapid induction of naive T cell apoptosis by ecto-nicotinamide adenine dinucleotide: Requirement for mono(ADP-ribosyl)transferase 2 and a downstream effector. J. Immunol. 2001, 167, 196-203. [CrossRef] [PubMed]

84. Nemoto, E.; Stohlman, S.; Dennert, G. Release of a glycosylphosphatidylinositol-anchored ADP-ribosyltransferase from cytotoxic T cells upon activation. J. Immunol. 1996, 156, 85-92.

85. Krebs, C.; Adriouch, S.; Braasch, F.; Koestner, W.; Leiter, E.H.; Seman, M.; Lund, F.E.; Oppenheimer, N.; Haag, F.; Koch-Nolte, F. CD38 controls ADP-ribosyltransferase-2-catalyzed ADP-ribosylation of T cell surface proteins. J. Immunol. 2005, 174, 3298-3305. [CrossRef]

86. Teege, S.; Hann, A.; Miksiewicz, M.; MacMillan, C.; Rissiek, B.; Buck, F.; Menzel, S.; Nissen, M.; Bannas, P.; Haag, F.; et al. Tuning IL-2 signaling by ADP-ribosylation of CD25. Sci. Rep. 2015, 5, 8959. [CrossRef]

87. Ray Chaudhuri, A.; Nussenzweig, A. The multifaceted roles of PARP1 in DNA repair and chromatin remodelling. Nat. Rev. Mol. Cell Biol. 2017, 18, 610-621. [CrossRef]

88. Rosado, M.M.; Bennici, E.; Novelli, F.; Pioli, C. Beyond DNA repair, the immunological role of PARP-1 and its siblings. Immunology 2013, 139, 428-437. [CrossRef]

89. Valdor, R.; Schreiber, V.; Saenz, L.; Martinez, T.; Munoz-Suano, A.; Dominguez-Villar, M.; Ramirez, P.; Parrilla, P.; Aguado, E.; Garcia-Cozar, F.; et al. Regulation of NFAT by poly(ADP-ribose) polymerase activity in T cells. Mol. Immunol. 2008, 45, 1863-1871. [CrossRef]

90. Olabisi, O.A.; Soto-Nieves, N.; Nieves, E.; Yang, T.T.; Yang, X.; Yu, R.Y.; Suk, H.Y.; Macian, F.; Chow, C.W. Regulation of transcription factor NFAT by ADP-ribosylation. Mol. Cell Biol. 2008, 28, 2860-2871. [CrossRef]

91. Bai, P.; Virag, L. Role of poly(ADP-ribose) polymerases in the regulation of inflammatory processes. FEBS Lett. 2012, 586, 3771-3777. [CrossRef] [PubMed]

92. Hassa, P.O.; Hottiger, M.O. The functional role of poly(ADP-ribose)polymerase 1 as novel coactivator of NF-kappaB in inflammatory disorders. Cell Mol. Life. Sci. 2002, 59, 1534-1553. [CrossRef] [PubMed]

93. Hassa, P.O.; Covic, M.; Hasan, S.; Imhof, R.; Hottiger, M.O. The enzymatic and DNA binding activity of PARP-1 are not required for NF-kappa B coactivator function. J. Biol. Chem. 2001, 276, 45588-45597. [CrossRef] [PubMed] 
94. Zerfaoui, M.; Errami, Y.; Naura, A.S.; Suzuki, Y.; Kim, H.; Ju, J.; Liu, T.; Hans, C.P.; Kim, J.G.; Abd Elmageed, Z.Y.; et al. Poly(ADP-ribose) polymerase-1 is a determining factor in Crm1-mediated nuclear export and retention of p65 NF-kappa B upon TLR4 stimulation. J. Immunol. 2010, 185, 1894-1902. [CrossRef]

95. Saenz, L.; Lozano, J.J.; Valdor, R.; Baroja-Mazo, A.; Ramirez, P.; Parrilla, P.; Aparicio, P.; Sumoy, L.; Yelamos, J. Transcriptional regulation by poly(ADP-ribose) polymerase-1 during T cell activation. BMC Genom. 2008, 9, 171. [CrossRef]

96. Datta, R.; Naura, A.S.; Zerfaoui, M.; Errami, Y.; Oumouna, M.; Kim, H.; Ju, J.; Ronchi, V.P.; Haas, A.L.; Boulares, A.H. PARP-1 deficiency blocks IL-5 expression through calpain-dependent degradation of STAT-6 in a murine asthma model. Allergy 2011, 66, 853-861. [CrossRef]

97. Zhang, P.; Maruyama, T.; Konkel, J.E.; Abbatiello, B.; Zamarron, B.; Wang, Z.Q.; Chen, W. PARP-1 controls immunosuppressive function of regulatory $\mathrm{T}$ cells by destabilizing Foxp3. PLoS ONE 2013, 8, e71590. [CrossRef]

98. Nasta, F.; Laudisi, F.; Sambucci, M.; Rosado, M.M.; Pioli, C. Increased Foxp3+ regulatory T cells in poly(ADP-Ribose) polymerase-1 deficiency. J. Immunol. 2010, 184, 3470-3477. [CrossRef]

99. Thoren, F.B.; Romero, A.I.; Hellstrand, K. Oxygen radicals induce poly(ADP-ribose) polymerase-dependent cell death in cytotoxic lymphocytes. J. Immunol. 2006, 176, 7301-7307. [CrossRef]

100. Carafa, V.; Nebbioso, A.; Altucci, L. Sirtuins and disease: The road ahead. Front. Pharm. 2012, 3, 4. [CrossRef]

101. Zhang, J.; Lee, S.M.; Shannon, S.; Gao, B.; Chen, W.; Chen, A.; Divekar, R.; McBurney, M.W.; Braley-Mullen, H.; Zaghouani, H.; et al. The type III histone deacetylase Sirt1 is essential for maintenance of $\mathrm{T}$ cell tolerance in mice. J. Clin. Investig. 2009, 119, 3048-3058. [CrossRef] [PubMed]

102. Nimmagadda, V.K.; Bever, C.T.; Vattikunta, N.R.; Talat, S.; Ahmad, V.; Nagalla, N.K.; Trisler, D.; Judge, S.I.; Royal, W., 3rd; Chandrasekaran, K.; et al. Overexpression of SIRT1 protein in neurons protects against experimental autoimmune encephalomyelitis through activation of multiple SIRT1 targets. J. Immunol. 2013, 190, 4595-4607. [CrossRef] [PubMed]

103. Gao, B.; Kong, Q.; Kemp, K.; Zhao, Y.S.; Fang, D. Analysis of sirtuin 1 expression reveals a molecular explanation of IL-2-mediated reversal of T-cell tolerance. Proc. Natl. Acad. Sci. USA 2012, 109, 899-904. [CrossRef]

104. Gao, Z.; Ye, J. Inhibition of transcriptional activity of c-JUN by SIRT1. Biochem. Biophys. Res. Commun. 2008, 376, 793-796. [CrossRef]

105. Attema, J.L.; Reeves, R.; Murray, V.; Levichkin, I.; Temple, M.D.; Tremethick, D.J.; Shannon, M.F. The human IL-2 gene promoter can assemble a positioned nucleosome that becomes remodeled upon $\mathrm{T}$ cell activation. J. Immunol. 2002, 169, 2466-2476. [CrossRef]

106. Kong, S.; Kim, S.J.; Sandal, B.; Lee, S.M.; Gao, B.; Zhang, D.D.; Fang, D. The type III histone deacetylase Sirt1 protein suppresses $\mathrm{p} 300$-mediated histone $\mathrm{H} 3$ lysine 56 acetylation at Bclaf1 promoter to inhibit $\mathrm{T}$ cell activation. J. Biol. Chem. 2011, 286, 16967-16975. [CrossRef]

107. Sequeira, J.; Boily, G.; Bazinet, S.; Saliba, S.; He, X.; Jardine, K.; Kennedy, C.; Staines, W.; Rousseaux, C.; Mueller, R.; et al. sirt1-null mice develop an autoimmune-like condition. Exp. Cell Res. 2008, 314, 3069-3074. [CrossRef]

108. Legutko, A.; Marichal, T.; Fievez, L.; Bedoret, D.; Mayer, A.; de Vries, H.; Klotz, L.; Drion, P.V.; Heirman, C.; Cataldo, D.; et al. Sirtuin 1 promotes Th2 responses and airway allergy by repressing peroxisome proliferator-activated receptor-gamma activity in dendritic cells. J. Immunol. 2011, 187, 4517-4529. [CrossRef]

109. Lim, H.W.; Kang, S.G.; Ryu, J.K.; Schilling, B.; Fei, M.; Lee, I.S.; Kehasse, A.; Shirakawa, K.; Yokoyama, M.; Schnolzer, M.; et al. SIRT1 deacetylates RORgammat and enhances Th17 cell generation. J. Exp. Med. 2015, 212, 607-617. [CrossRef]

110. Limagne, E.; Thibaudin, M.; Euvrard, R.; Berger, H.; Chalons, P.; Vegan, F.; Humblin, E.; Boidot, R.; Rebe, C.; Derangere, V.; et al. Sirtuin-1 Activation Controls Tumor Growth by Impeding Th17 Differentiation via STAT3 Deacetylation. Cell Rep. 2017, 19, 746-759. [CrossRef]

111. Wang, J.; Zhao, C.; Kong, P.; Sun, H.; Sun, Z.; Bian, G.; Sun, Y.; Guo, L. Treatment with NAD(+) inhibited experimental autoimmune encephalomyelitis by activating AMPK/SIRT1 signaling pathway and modulating Th1/Th17 immune responses in mice. Int. Immunopharmacol. 2016, 39, 287-294. [CrossRef] [PubMed] 
112. Van Loosdregt, J.; Vercoulen, Y.; Guichelaar, T.; Gent, Y.Y.; Beekman, J.M.; van Beekum, O.; Brenkman, A.B.; Hijnen, D.J.; Mutis, T.; Kalkhoven, E.; et al. Regulation of Treg functionality by acetylation-mediated Foxp3 protein stabilization. Blood 2010, 115, 965-974. [CrossRef] [PubMed]

113. Beier, U.H.; Wang, L.; Bhatti, T.R.; Liu, Y.; Han, R.; Ge, G.; Hancock, W.W. Sirtuin-1 targeting promotes Foxp3+ T-regulatory cell function and prolongs allograft survival. Mol. Cell Biol. 2011, 31, 1022-1029. [CrossRef] [PubMed]

114. Deng, G.; Song, X.; Fujimoto, S.; Piccirillo, C.A.; Nagai, Y.; Greene, M.I. Foxp3 Post-translational Modifications and Treg Suppressive Activity. Front. Immunol. 2019, 10, 2486. [CrossRef]

115. Van Loosdregt, J.; Brunen, D.; Fleskens, V.; Pals, C.E.; Lam, E.W.; Coffer, P.J. Rapid temporal control of Foxp3 protein degradation by sirtuin-1. PLoS ONE 2011, 6, e19047. [CrossRef]

116. Kwon, H.S.; Lim, H.W.; Wu, J.; Schnolzer, M.; Verdin, E.; Ott, M. Three novel acetylation sites in the Foxp3 transcription factor regulate the suppressive activity of regulatory T cells. J. Immunol. 2012, 188, 2712-2721. [CrossRef]

117. Ruan, Q.; Kameswaran, V.; Tone, Y.; Li, L.; Liou, H.C.; Greene, M.I.; Tone, M.; Chen, Y.H. Development of Foxp3(+) regulatory $t$ cells is driven by the c-Rel enhanceosome. Immunity 2009, 31, 932-940. [CrossRef]

118. Elibol, B.; Kilic, U. High Levels of SIRT1 Expression as a Protective Mechanism Against Disease-Related Conditions. Front. Endocrinol. 2018, 9, 614. [CrossRef]

119. Chang, H.C.; Guarente, L. SIRT1 and other sirtuins in metabolism. Trends Endocrinol. Metab. 2014, 25, $138-145$. [CrossRef]

120. Geltink, R.I.K.; Kyle, R.L.; Pearce, E.L. Unraveling the Complex Interplay Between T Cell Metabolism and Function. Annu. Rev. Immunol. 2018, 36, 461-488. [CrossRef]

121. Camacho-Pereira, J.; Tarrago, M.G.; Chini, C.C.S.; Nin, V.; Escande, C.; Warner, G.M.; Puranik, A.S.; Schoon, R.A.; Reid, J.M.; Galina, A.; et al. CD38 Dictates Age-Related NAD Decline and Mitochondrial Dysfunction through an SIRT3-Dependent Mechanism. Cell Metab. 2016, 23, 1127-1139. [CrossRef] [PubMed]

122. Hu, Y.; Wang, H.; Wang, Q.; Deng, H. Overexpression of CD38 decreases cellular NAD levels and alters the expression of proteins involved in energy metabolism and antioxidant defense. J. Proteome Res. 2014, 13, 786-795. [CrossRef] [PubMed]

123. Mak, T.W.; Grusdat, M.; Duncan, G.S.; Dostert, C.; Nonnenmacher, Y.; Cox, M.; Binsfeld, C.; Hao, Z.; Brustle, A.; Itsumi, M.; et al. Glutathione Primes T Cell Metabolism for Inflammation. Immunity 2017, 46, 675-689. [CrossRef] [PubMed]

124. Vellinga, T.T.; Borovski, T.; de Boer, V.C.; Fatrai, S.; van Schelven, S.; Trumpi, K.; Verheem, A.; Snoeren, N.; Emmink, B.L.; Koster, J.; et al. SIRT1/PGC1alpha-Dependent Increase in Oxidative Phosphorylation Supports Chemotherapy Resistance of Colon Cancer. Clin. Cancer Res. 2015, 21, 2870-2879. [CrossRef]

125. Abraham, A.; Qiu, S.; Chacko, B.K.; Li, H.; Paterson, A.; He, J.; Agarwal, P.; Shah, M.; Welner, R.; Darley-Usmar, V.M.; et al. SIRT1 regulates metabolism and leukemogenic potential in CML stem cells. J. Clin. Investig. 2019, 129, 2685-2701. [CrossRef]

126. Brenmoehl, J.; Hoeflich, A. Dual control of mitochondrial biogenesis by sirtuin 1 and sirtuin 3. Mitochondrion 2013, 13, 755-761. [CrossRef] [PubMed]

127. Tang, B.L. Sirt1 and the Mitochondria. Mol. Cells 2016, 39, 87-95. [CrossRef]

128. Van der Windt, G.J.; Everts, B.; Chang, C.H.; Curtis, J.D.; Freitas, T.C.; Amiel, E.; Pearce, E.J.; Pearce, E.L. Mitochondrial respiratory capacity is a critical regulator of CD8+ T cell memory development. Immunity 2012, 36, 68-78. [CrossRef] [PubMed]

129. Buck, M.D.; O’Sullivan, D.; Klein Geltink, R.I.; Curtis, J.D.; Chang, C.H.; Sanin, D.E.; Qiu, J.; Kretz, O.; Braas, D.; van der Windt, G.J.; et al. Mitochondrial Dynamics Controls T Cell Fate through Metabolic Programming. Cell 2016, 166, 63-76. [CrossRef]

130. Kelly, T.J.; Lerin, C.; Haas, W.; Gygi, S.P.; Puigserver, P. GCN5-mediated transcriptional control of the metabolic coactivator PGC-1beta through lysine acetylation. J. Biol. Chem. 2009, 284, 19945-19952. [CrossRef]

131. Picard, F.; Kurtev, M.; Chung, N.; Topark-Ngarm, A.; Senawong, T.; Machado De Oliveira, R.; Leid, M.; McBurney, M.W.; Guarente, L. Sirt1 promotes fat mobilization in white adipocytes by repressing PPAR-gamma. Nature 2004, 429, 771-776. [CrossRef]

132. Chakraborty, P.; Vaena, S.G.; Thyagarajan, K.; Chatterjee, S.; Al-Khami, A.; Selvam, S.P.; Nguyen, H.; Kang, I.; Wyatt, M.W.; Baliga, U.; et al. Pro-Survival Lipid Sphingosine-1-Phosphate Metabolically Programs T Cells to Limit Anti-tumor Activity. Cell Rep. 2019, 28, 1879-1893. [CrossRef] [PubMed] 
133. O'Sullivan, D.; van der Windt, G.J.W.; Huang, S.C.; Curtis, J.D.; Chang, C.H.; Buck, M.D.; Qiu, J.; Smith, A.M.; Lam, W.Y.; DiPlato, L.M.; et al. Memory CD8(+) T Cells Use Cell-Intrinsic Lipolysis to Support the Metabolic Programming Necessary for Development. Immunity 2018, 49, 375-376. [CrossRef] [PubMed]

134. Chen, Y.; Zander, R.; Khatun, A.; Schauder, D.M.; Cui, W. Transcriptional and Epigenetic Regulation of Effector and Memory CD8 T Cell Differentiation. Front. Immunol. 2018, 9, 2826. [CrossRef] [PubMed]

135. Lu, C.; Thompson, C.B. Metabolic regulation of epigenetics. Cell Metab. 2012, 16, 9-17. [CrossRef] [PubMed]

136. Kietzmann, T.; Petry, A.; Shvetsova, A.; Gerhold, J.M.; Gorlach, A. The epigenetic landscape related to reactive oxygen species formation in the cardiovascular system. Br. J. Pharm. 2017, 174, 1533-1554. [CrossRef]

137. Suzuki, J.; Yamada, T.; Inoue, K.; Nabe, S.; Kuwahara, M.; Takemori, N.; Takemori, A.; Matsuda, S.; Kanoh, M.; Imai, Y.; et al. The tumor suppressor menin prevents effector CD8 T-cell dysfunction by targeting mTORC1-dependent metabolic activation. Nat. Commun. 2018, 9, 3296. [CrossRef]

138. Xu, T.; Stewart, K.M.; Wang, X.; Liu, K.; Xie, M.; Ryu, J.K.; Li, K.; Ma, T.; Wang, H.; Ni, L.; et al. Metabolic control of TH17 and induced Treg cell balance by an epigenetic mechanism. Nature 2017, 548, 228-233. [CrossRef]

139. Klysz, D.; Tai, X.; Robert, P.A.; Craveiro, M.; Cretenet, G.; Oburoglu, L.; Mongellaz, C.; Floess, S.; Fritz, V.; Matias, M.I.; et al. Glutamine-dependent alpha-ketoglutarate production regulates the balance between $\mathrm{T}$ helper 1 cell and regulatory T cell generation. Sci. Signal. 2015, 8, ra97. [CrossRef] [PubMed]

140. Jing, H.; Lin, H. Sirtuins in epigenetic regulation. Chem. Rev. 2015, 115, 2350-2375. [CrossRef]

141. Rifai, K.; Judes, G.; Idrissou, M.; Daures, M.; Bignon, Y.J.; Penault-Llorca, F.; Bernard-Gallon, D. SIRT1-dependent epigenetic regulation of $\mathrm{H} 3$ and $\mathrm{H} 4$ histone acetylation in human breast cancer. Oncotarget 2018, 9, 30661-30678. [CrossRef] [PubMed]

142. Araki, Y.; Fann, M.; Wersto, R.; Weng, N.P. Histone acetylation facilitates rapid and robust memory CD8 T cell response through differential expression of effector molecules (eomesodermin and its targets: Perforin and granzyme B). J. Immunol. 2008, 180, 8102-8108. [CrossRef] [PubMed]

143. Katsuyama, E.; Suarez-Fueyo, A.; Bradley, S.J.; Mizui, M.; Marin, A.V.; Mulki, L.; Krishfield, S.; Malavasi, F.; Yoon, J.; Sui, S.J.H.; et al. The CD38/NAD/SIRTUIN1/EZH2 Axis Mitigates Cytotoxic CD8 T Cell Function and Identifies Patients with SLE Prone to Infections. Cell Rep. 2020, 30, 112-123.e4. [CrossRef] [PubMed]

144. Tumes, D.J.; Onodera, A.; Suzuki, A.; Shinoda, K.; Endo, Y.; Iwamura, C.; Hosokawa, H.; Koseki, H.; Tokoyoda, K.; Suzuki, Y.; et al. The polycomb protein Ezh2 regulates differentiation and plasticity of CD4(+) T helper type 1 and type 2 cells. Immunity 2013, 39, 819-832. [CrossRef] [PubMed]

145. Yang, X.P.; Jiang, K.; Hirahara, K.; Vahedi, G.; Afzali, B.; Sciume, G.; Bonelli, M.; Sun, H.W.; Jankovic, D.; Kanno, Y.; et al. EZH2 is crucial for both differentiation of regulatory $\mathrm{T}$ cells and T effector cell expansion. Sci. Rep. 2015, 5, 10643. [CrossRef] [PubMed]

146. Xiao, X.Y.; Li, Y.T.; Jiang, X.; Ji, X.; Lu, X.; Yang, B.; Wu, L.J.; Wang, X.H.; Guo, J.B.; Zhao, L.D.; et al. EZH2 deficiency attenuates Treg differentiation in rheumatoid arthritis. J. Autoimmun. 2020, 108, 102404. [CrossRef]

147. Van de Donk, N.; Usmani, S.Z. CD38 Antibodies in Multiple Myeloma: Mechanisms of Action and Modes of Resistance. Front. Immunol. 2018, 9, 2134. [CrossRef]

(C) 2020 by the authors. Licensee MDPI, Basel, Switzerland. This article is an open access article distributed under the terms and conditions of the Creative Commons Attribution (CC BY) license (http://creativecommons.org/licenses/by/4.0/). 